\title{
$17 \beta$-Estradiol affects the innate immune response in common carp
}

\author{
Magdalena Maciuszek • Lukasz Pijanowski • \\ Agnieszka Pekala-Safinska • B. M. Lidy Verburg-van \\ Kemenade $•$ Magdalena Chadzinska $(\mathbb{D}$
}

Received: 12 February 2020 / Accepted: 21 May 2020 /Published online: 9 June 2020

(C) The Author(s) 2020

\begin{abstract}
Inflammation is the evolutionary conserved immune response to harmful stimuli such as pathogens or damaged cells. This multistep process acts by removing injurious stimuli and initiating the healing process. Therefore, it must be tightly regulated by cytokines, chemokines, and enzymes, as well as neuroendocrine mediators. In the present work, we studied the immunoregulatory properties of $17 \beta$-estradiol (E2) in common carp. We determined the in vitro effects of E2 on the activity/polarization of macrophages and the in vivo effects during Aeromonas salmonicida-induced inflammation. In vitro, E2 reduced the lipopolysaccharide (LPS)-stimulated expression of pro- and antiinflammatory mediator genes but did not change the gene expression of the estrogen receptors and of aromatase CYP19. In contrast, in vivo in the head kidney of A. salmonicida-infected fish, E2-treated feeding in-
\end{abstract}

Electronic supplementary material The online version of this article (https://doi.org/10.1007/s10695-020-00827-3) contains supplementary material, which is available to authorized users.

M. Maciuszek · L. Pijanowski · M. Chadzinska $(\bowtie)$ Department of Evolutionary Immunology, Institute of Zoology and Biomedical Research, Faculty of Biology, Jagiellonian University, Gronostajowa 9, PL30-387 Krakow, Poland e-mail: magdalena.chadzinska@uj.edu.pl
A. Pekala-Safinska
Department of Fish Diseases, National Veterinary Research Institute, Partyzantow Avenue 57, PL24-100 Pulawy, Poland
B. M. L. V.-v. Kemenade
Cell Biology and Immunology Group, Wageningen University, P.O. Box 338, 6700AH Wageningen, The Netherlands

duced an upregulation of gene expression of proinflammatory (il-12p35 and $c x c b 2$ ) and antiinflammatory (arginase 1, arginase 2, il-10, and mmp9) mediators. Moreover, in infected fish fed with E2-treated food, a higher gene expression of the estrogen receptors and of the aromatase CYP19 was found. Our results demonstrate that estrogens can modulate the carp innate immune response, though the in vitro and in vivo effects of this hormone are contrasting. This implies that estradiol not only induces a direct effect on macrophages but rather exerts immunomodulatory actions through indirect mechanisms involving other cellular targets.

Keywords Estrogens · Inflammation · Macrophage polarization $\cdot$ Fish $\cdot$ Bacterial infection

\section{Introduction}

The innate immune response is the first line of defense against pathogens. Although fish are the earliest vertebrates with an adaptive immune response, they still rely mostly on their innate response (Magnadóttir 2006). As in mammals, the professional phagocytes (macrophages and granulocytes) in fish are also the executive cells of the innate response/inflammation. They migrate to the site of inflammation and eliminate pathogens through phagocytosis. Additionally, they produce reactive oxygen species (ROS), enzymes (e.g., lysozyme, neutrophil elastase, and matrix metalloproteinase 9 (MMP9)), and antimicrobial peptides that are all toxic to pathogens. As 
these latter molecules can be also toxic for host cells and tissues, phagocyte activation has to be tightly regulated by cytokines (Chadzinska et al. 2008b). During the first phase of inflammation, pro-inflammatory cytokines (e.g., interleukins: IL-1 $\beta$, IL-12, and tumor necrosis factor (TNF- $\alpha)$ ) activate phagocytes while their migration is directed by chemokines (e.g., CXCL8/IL8 and $\mathrm{CXCb}$ ) (van der Aa et al. 2012). In turn, after pathogen eradication, the anti-inflammatory phase takes place when anti-inflammatory cytokines such as IL-10 and IL-1 receptor antagonist (IL-1Ra) orchestrate the resolution of inflammation and tissue repair. The cytokine milieu thus determines the status of cell activation/ polarization and thereby the direction of the immune response. Both in mammals and fish, classical proinflammatory (M1) polarization of macrophages takes place upon stimulation with pro-inflammatory TNF- $\alpha$ and/or interferon gamma (INF- $\gamma$ ) and in contact with bacterial lipopolysaccharide (LPS). M1 macrophages exhibit a higher expression of pro-inflammatory cytokines (IL-1 $\beta$, IL-12) and CXC chemokines, and they produce ROS (Arts et al. 2010). This results in a shift of the immune response to a cellular response, involving Th1 lymphocytes (Martinez and Gordon 2014). In contrast, upon stimulation with the anti-inflammatory cytokines IL-10, IL-4, or IL-13, macrophages exhibit an anti-inflammatory M2 phenotype. M2 macrophages are characterized by higher production of antiinflammatory cytokines (IL-4, IL-10, IL-13) (Montero et al. 2016; Mao et al. 2018). These mechanisms lead to a shift of the immune reaction towards a humoral response with Th2 lymphocytes, immunoregulation, remodeling of the matrix, tissue repair, and silencing of inflammation. M1 and M2 polarization of macrophages is strongly associated with the internal metabolism of Larginine. Whereas the M1 cells increase their expression of inducible nitric oxide synthase (iNOS), converting Larginine to N-hydroxy-L-arginine, which results in increased production of nitric oxide (NO), M2 cells increase expression of the arginase, converting L-arginine to urea and L-ornithine. Consequently, polyamines and prolines are formed, which are essential for cell proliferation and tissue repair (Joerink et al. 2006; Rath et al. 2014). Several other proteins such as cysteine-rich angiogenic inducer 61 protein (cyr61), inhibin, and MMP9 are involved in the process of wound healing and tissue regeneration (Bai et al. 2005; Ogawa et al. 2006; Lau 2011; Derlindati et al. 2015). Another group of molecules involved both in pathogen eradication and in host tissue protection during inflammation are liver-derived acute phase proteins (APPs) such as C-reactive protein (CRP), serum amyloid P (SAP), and complement proteins such as C3 (Bayne and Gerwick 2001).

Next to immune-related factors (cytokines, APPs) also hormones are strongly implicated in the regulation of the inflammatory reaction/macrophage polarization (Verburg-van Kemenade et al. 2017). Recently, we found, for example, that both the in vitro and the in vivo polarization of carp macrophages are affected by cortisol (Maciuszek et al. 2019). We also observed that $17 \beta$-estradiol (E2) affects the in vitro activity of fish macrophages and that this process is mediated via the membrane estrogen receptor GPR30 (Szwejser et al. 2017a). Moreover, we and others found that fish leukocytes also express nuclear estrogen receptors (ER $\alpha$ and ER $\beta$ ) (Liarte et al. 2011b; Iwanowicz et al. 2014; Burgos-Aceves et al. 2016; Szwejser et al. 2017a; Paiola et al. 2019). Furthermore, fish leukocytes have been shown to express aromatase - cyp $19 a$ and cyp $19 b$ genes encoding aromatase P450, responsible for the conversion of testosterone to $17 \beta$-estradiol (Szwejser et al. 2017b). This implicates direct auto- or intra-crine regulation of the immune response by estrogens (Matthews and Gustafsson 2003; Hawkins and Thomas 2004; Katsu et al. 2013; Szwejser et al. 2017a). And indeed, estrogen has been shown to affect the innate response by modulating the production of ROS, NO, and cytokines (Watanuki et al. 2002; Thilagam et al. 2009; Liarte et al. 2011b; Cabas et al. 2012; Szwejser et al. 2017a; Paiola et al. 2019). It also affected phagocytosis and lysozyme activity (Wang and Belosevic 1995; Law et al. 2001; Yamaguchi et al. 2001; Watanuki et al. 2002; Thilagam et al. 2009; Liarte et al. 2011b; Akbary et al. 2013). Furthermore, it was found that E2 may modulate fish susceptibility to infection by altering leukocyte activity. For example, E2 increased the mortality of fish infected with Trypanosoma danilewskyi (Wang and Belosevic 1994) while rainbow trout exposed to E2 had higher susceptibility to bacterial infection of Yersinia ruckeri and consequently decreased survival rates (Wenger et al. 2011). Moreover, E2 increased susceptibility to viral infection of spring viraemia of carp virus (SVCV) in larvae and in adult zebrafish (López-Muñoz et al. 2015). In contrast, E2 enhanced protection against lice in Atlantic salmon (Krasnov et al. 2015). However, it should be mentioned that the immunoregulatory actions of estrogens vary among fish species, and also with dose, target cell type, or physiological condition (e.g., 
infection load, stress level, reproductive status) (Szwejser et al. 2017b, c).

In the present work, we examined how E2 may affect the response of carp monocytes/macrophages upon bacterial infection. We studied the in vitro reaction against bacterial lipopolysaccharide. Subsequently, we studied the in vivo inflammatory reaction evoked by an Aeromonas salmonicida-induced bacterial infection. For this purpose, we measured the effect on expression of the most important pro- and anti-inflammatory mediators. To better clarify the potential mechanism of E2 action, we moreover studied the expression of the nuclear and membrane estrogen receptors and the aromatase cyp19 enzyme.

\section{Materials and methods}

\section{Animals}

Young, sexually immature individuals of common carp (Cyprinus carpio L; line R3xR8) were obtained from the Institute of Ichthyobiology and Aquaculture, Polish Academy of Sciences, Golysz, Poland. Fish used for treatment groups within one experiment were from one breed, and to limit potential differences between experiments, we always used fish aged 9 to 12 months that have a welldeveloped mature immune system. Studies were conducted in the spring (March/April 2019). Prior to the experiments, fish were adapted for 4 weeks at $21{ }^{\circ} \mathrm{C}$ in recirculating tap water at the Institute of Zoology and Biomedical Research in Krakow, Poland. Fish were kept in tanks (volume $375 \mathrm{~L}$, flow rate $4 \mathrm{~L} / \mathrm{min}$, density 45 fish/tank and $60 \mathrm{~g} / \mathrm{L}$ ) and fed pelleted dry food (Aller Master, Aller Aqua, Poland) at a daily maintenance rate of $1 \%$ of their estimated body weight, in photoperiod 13L:11D. In order to avoid additional stress and/or differences in handling, all samplings were performed by the same person and at the same time of day (at 9:00 a.m.).

All animals were handled in strict accordance with good animal practice as defined by the relevant national and local animal welfare bodies, and procedures were approved by the local ethical committee (2nd Local Institutional Animal Care and Use Committee (IACUC) in Krakow, Poland, license number 291/ 2017).
E2 treatment

After acclimation, fish were randomly divided into 2 different treatment groups: non-E2 - fed with control food $(n=14)$ or E2 - fed with food treated with E2 (20 mg E2/kg food, Sigma-Aldrich, St. Louis, MO, USA) $(n=14)$. The weight of the animals from both groups before the start of the experiment did not differ significantly and was $65.1 \mathrm{~g} \pm 11.75$ for control fish and $56.14 \mathrm{~g} \pm 9.18$ for experimental animals. The E2 concentration was chosen and the food was prepared as described before (Wenger et al. 2011) from commercially available dry food (Aller Master, Aller Aqua, Poland) which was spiked with E2 diluted in ethanol (99.8\%, POCH, Gliwice, Poland) and processed by alcohol evaporation method-E2 (Guerrero 1975) with some modification: food was dried for $2 \mathrm{~h}$ at room temperature. Control food (non-E2) was spiked with the same volume of ethanol alone. Fish were fed at a daily maintenance rate of $1 \%$ of their estimated body weight for 14 days. After the feeding period, the weight of control and E2-treated fish did not differ significantly and was $72.4 \mathrm{~g} \pm 3.5$ and $64.3 \mathrm{~g} \pm 3.3$, respectively. Efficiency of E2 treatment was confirmed by measurement of the increased E2 serum levels and of the upregulation of vitellogenin gene expression in the liver of fish fed with E2-treated food compared to animals fed with control non-E2 food (Fig. 5).

Infection

A. salmonicida subsp. salmonicida from Polish origin was obtained from the Department of Fish Diseases, National Veterinary Research Institute, Pulawy. Bacteria were grown in lysogeny broth (LB) medium for $18 \mathrm{~h}$ at $25^{\circ} \mathrm{C}$ and centrifuged at $1600 \mathrm{~g}$ for $10 \mathrm{~min}$, and the bacterial pellet reconstituted in sterile PBS (280 mOsM). Optical density was measured at $625 \mathrm{~nm}$, and data were aligned with a previously derived McFarland scale to determine the bacterial concentration. On day 14 of feeding, fish from both E2 and non-E2 groups $(n=7)$ were injected intraperitoneally (i.p.) with a non-lethal dose of A. salmonicida $\left(4 \times 10^{8}\right.$ bacteria in $250 \mu \mathrm{L}$ PBS per fish) as described previously (Falco et al. 2012). Fish were sacrificed at 24 and $96 \mathrm{~h}$ post-injection (hpi). Fish were anesthetized with tricaine methane sulfonate (TMS; Sigma-Aldrich, St. Louis, MO, USA; $0.2 \mathrm{~g} / \mathrm{L}$ ) buffered with $\mathrm{NaHCO}_{3}$ (POCH, Gliwice, Poland; $0.4 \mathrm{~g} / \mathrm{L}$ ). 


\section{Serum hormone level}

Fish were bled immediately post anesthesia through puncture of the caudal vein using a needle attached to a 5-mL syringe. The samples were taken midline, just posterior of the anal fin. Each time, approximately $5 \mathrm{~mL}$ of blood was removed from the caudal vein into the syringe. Blood was collected in covered test tubes and allowed to clot overnight at $4{ }^{\circ} \mathrm{C}$. Blood clots were removed by centrifuging at $3000 \times \mathrm{g}$ for $30 \mathrm{~min}$, and serum was collected and stored at $-20{ }^{\circ} \mathrm{C}$ for future use. Estradiol level was determined using the commercial kit DRG (Marburg, Germany; range 10.6-2000 pg/ $\mathrm{mL}$, sensitivity $10.60 \mathrm{pg} / \mathrm{mL}$ ). On the day of the assay, blood serum samples were thawed and used according to the manufacturer's protocol. All standards and samples from every individual fish were analyzed in duplicate, in the same batch.

\section{Organ and cell isolation}

After the bleeding, peritoneal leukocytes (PTL) were taken by flushing the peritoneal cavity with $2 \mathrm{~mL}$ of sterile PBS (280 mOsM) with heparin (Leo Pharmaceutical Products Ltd., Weesp, the Netherlands) as described previously (Chadzinska et al. 2008b). To determine the composition of peritoneal leukocytes, the phagocytes (mononuclear and polymorphonuclear leukocytes) and lymphocytes were counted in a hemocytometer after Türk staining $(0.01 \%(\mathrm{w} / \mathrm{v})$ crystal violet (Sigma-Aldrich, St. Louis, MO, USA) in 3\% (v/v) acetic acid (POCH, Gliwice, Poland) which allows distinction of the smaller, spherical lymphocytes with a round nucleus and a small non-granular cytoplasm from the bigger, granular phagocytes with irregular-shaped nucleus (Chadzinska et al. 2008b).

Organs (head kidney and liver) were carefully removed and immediately transferred to fix RNA buffer (Eurex, Gdansk, Poland) and kept at $-20^{\circ} \mathrm{C}$ for further analysis.

In vitro cell isolation and stimulation

Monocyte/macrophage suspensions were obtained by passing the head kidney tissue from intact fish through a 100- $\mu$ m nylon mesh with carp RPMI (cRPMI 1640, Invitrogen, Carlsbad, CA, adjusted to carp osmolarity of $270 \mathrm{mOsm} / \mathrm{kg}$ with distilled water) containing heparin (Leo Pharmaceutical Products Ltd., Weesp, the
Netherlands) and washed once as described previously (Maciuszek et al. 2019). This cell suspension was layered on a discontinuous Percoll gradient (1.020, 1.060, 1.070 , and $1.083 \mathrm{~g} / \mathrm{cm}^{3}$ ) to retrieve enriched populations of monocytes/macrophages $\left(1.060 \mathrm{~g} / \mathrm{cm}^{3}\right)$ and centrifuged for $30 \mathrm{~min}$ at $800 \times \mathrm{g}$ with the brake disengaged (Verburg-van Kemenade et al. 1994). Cell fractions were collected and washed. To verify the purity of the isolated cell populations, the monocyte/macrophageenriched cell population was stained with neutral red (NR) $(0.1 \mathrm{mg} / \mathrm{mL} ; 3 \mathrm{~min}$, at RT; Sigma-Aldrich, USA) or with Türk's solution for $3 \mathrm{~min}$ at RT and analyzed in a hemocytometer under a light microscope. Additionally, with a FACScalibur flow cytometer (BD Biosciences), 30,000 threshold events per sample were analyzed for their forward scatter (FSC) (for cell size) and sideward scatter (SSC) (cell complexity) profiles. Data were analyzed using WinMDI 2.9 software (Joe Trotter, http://facs.scripps.edu).

Cell fractions obtained from the head kidney contained an abundance of macrophages $(48.86 \% \pm$ 1.38) (Maciuszek et al. 2019).

The monocyte/macrophage-enriched suspensions were resuspended in carp cRPMI++ (cRPMI supplemented with $0.5 \%(\mathrm{v} / \mathrm{v})$ pooled carp serum with antibiotics (1\%(v/v) L-glutamine (Sigma-Aldrich, St. Louis, MO, USA), $1 \%$ (v/v) penicillin G (Sigma-Aldrich, St. Louis, MO, USA) and $1 \%(\mathrm{v} / \mathrm{v})$ streptomycin sulfate (Sigma-Aldrich, St. Louis, MO, USA)) to a density of 10 million cells per $\mathrm{mL}$. The E2 level in cRPMI++ medium was measured as described previously (Szwejser et al. 2017b) and was below detection level.

To determine gene expression, monocytes/ macrophages were seeded in 24-well plate cell culture plates (Nest Biotech Co, Wuxi, China) at $27{ }^{\circ} \mathrm{C}, 5 \%$ $\mathrm{CO}_{2}$. The cells were treated either with $1 \mu \mathrm{M}$ E2 (Sigma-Aldrich, St. Louis, MO, USA) or $30 \mu \mathrm{g} / \mathrm{mL}$ LPS (Escherichia coli serotype O55: B5, Sigma-Aldrich, St. Louis, MO, USA; L2880) or their combination (1 $\mu \mathrm{M}$ $\mathrm{E} 2+30 \mu \mathrm{g} / \mathrm{mL}$ LPS). E2 and LPS concentrations were chosen based on our previous studies (Szwejser et al. 2017a).

The E2 stock $(20 \mu \mathrm{g} / \mathrm{mL})$ was prepared in $100 \%$ ethanol and further diluted in culture medium. Control cells (CTR) were treated with the same volume of vehicle diluted in culture medium. After $6 \mathrm{~h}$ of stimulation, the cells were resuspended in $350 \mu \mathrm{L}$ RL buffer (Eurex, Gdansk, Poland) with $1 \%(\mathrm{v} / \mathrm{v}) \beta 2-$ 
mercaptoethanol (Sigma-Aldrich, St. Louis, MO, USA) and kept in $-80{ }^{\circ} \mathrm{C}$ for further analyses.

To determine cell activity (arginase activity and NO production), monocytes/macrophages were seeded in 96-well plate cell culture plates (Nest Biotech Co, Wuxi, China) at $27{ }^{\circ} \mathrm{C}, 5 \% \mathrm{CO}_{2}$ for $24 \mathrm{~h}$ and stimulated with E2, LPS, or E2 + LPS. The in vitro experiments were performed 3 times independently, and each time, monocyte/macrophage primary cultures were made from 1 or 2 fish.

\section{Arginase activity}

Arginase activity was measured as described by Corraliza et al. (1994). Cells were lysed with $50 \mu \mathrm{L}$ of $0.1 \%(\mathrm{v} / \mathrm{v})$ Triton X-100 containing $5 \mu \mathrm{g}$ of pepstatin (Sigma-Aldrich, St. Louis, MO, USA), $5 \mu \mathrm{g}$ of aprotinin (Sigma-Aldrich, St. Louis, MO, USA), and $5 \mu \mathrm{g}$ of antipain (Sigma-Aldrich, St. Louis, MO, USA), at room temperature for $30 \mathrm{~min}$. After incubation, $35 \mu \mathrm{L}$ of $10 \mathrm{mM} \mathrm{MnCl} 2$ (Sigma-Aldrich, St. Louis, MO, USA) and $50 \mathrm{mM}$ Tris-HCl (pH 7.5) (Tris - Biorad, USA; HCl-POCh, Gliwice, Poland) were added to each sample and the mixture was incubated for $20 \mathrm{~min}$ at $55^{\circ} \mathrm{C}$. To $50 \mu \mathrm{L}$ of this activated lysate, $50 \mu \mathrm{L}$ of $0.5 \mathrm{M} \mathrm{L}-$ arginine ( $\mathrm{pH}$ 9.7) (Sigma-Aldrich, St. Louis, MO, USA) was added and incubated for $1 \mathrm{~h}$ at $37^{\circ} \mathrm{C}$. The reaction was stopped by adding $400 \mu \mathrm{L}$ of an acid mixture containing $\mathrm{H}_{2} \mathrm{SO}_{4}$ (POCh, Gliwice, Poland), $\mathrm{H}_{3} \mathrm{PO}_{4}$ (Chempur, Piekary Slaskie, Polska), and $\mathrm{H}_{2} \mathrm{O}$ (1:3:7). In the next step, $25 \mu \mathrm{L}$ of $9 \%(\mathrm{v} / \mathrm{v}) \alpha-$ isonitrosopropiophenone (Sigma-Aldrich, St. Louis, MO, USA) in $100 \%$ ethanol $(99.8 \%$, POCH, Gliwice, Poland) was added to each sample. Samples were incubated for $45 \mathrm{~min}$ at $100{ }^{\circ} \mathrm{C}$. After $10 \mathrm{~min}$ cooling in the dark, the OD was read at $540 \mathrm{~nm}$, and the arginase activity was calculated by comparison with a urea standard curve $(0-6.66 \mathrm{mM})$.

Nitric oxide production

Nitrite/nitrate production, an indicator of nitric oxide synthesis, was measured in cell culture supernatants as described previously (Chadzinska et al. 2009). Following $24 \mathrm{~h}$ incubation, $100 \mu \mathrm{L}$ cell culture supernatant was added to $50 \mu \mathrm{L} 1 \%(\mathrm{w} / \mathrm{v})$ sulfanilamide in $2.5 \%(\mathrm{v} / \mathrm{v})$ phosphoric acid and $50 \mu \mathrm{L}$ of $0.1 \%$ (w/v) N-naphthylethylene-diamine in $2.5 \%(\mathrm{v} / \mathrm{v})$ phosphoric acid (all from Sigma-Aldrich, St. Louis, MO, USA). The OD reading at $540 \mathrm{~nm}$ (with $690 \mathrm{~nm}$ as a reference) was taken using the cRPMI++ medium as blank. Nitrite concentration was calculated by comparison with a sodium nitrite standard curve $(0-10 \mu \mathrm{M})$.

Gene expression

\section{RNA isolation}

RNA was isolated from cells and tissues with a GeneMATRIX Universal RNA Purification Kit (Eurex, Gdansk, Poland) according to the manufacturer's protocol. Final elution was carried out in $30 \mu \mathrm{L}$ of nucleasefree water, to maximize the concentration of RNA. Before proceeding with further analyses, RNA was quantified, and its integrity checked (Tecan Spark NanoQuant Plate $\left.{ }^{\mathrm{TM}}\right)$. Samples were stored at $-80^{\circ} \mathrm{C}$.

cDNA synthesis

For each sample, a non-reverse transcriptase (non-RT) control was included. The cDNA synthesis was performed with High-Capacity cDNA Reverse Transcription Kits (Applied Biosystems, Waltham, MA, USA) according to the manufacturer's protocol. Briefly, $1 \mu \mathrm{g}$ of total RNA was added to $10 \mu \mathrm{L}$ RT master mix containing $2 \mu \mathrm{L}$ 10X RT buffer, $0.8 \mu \mathrm{L} 25 \mathrm{XdNTP}$ $\operatorname{mix}(100 \mathrm{mM}), 2 \mu \mathrm{L}$ 10XRT random primers, $1 \mu \mathrm{L}$ MultiSribe $^{\mathrm{TM}}$ reverse transcriptase, and $4.2 \mu \mathrm{L}$ of nuclease-free water. The samples were then placed into the thermal cycler (Ditabis AG, Pforzheim, Germany; $25^{\circ} \mathrm{C}$ at $10 \mathrm{~min}, 37^{\circ} \mathrm{C}$ at $120 \mathrm{~min}, 85^{\circ} \mathrm{C}$ at $5 \mathrm{~min}$ followed by rapid cooling to $4{ }^{\circ} \mathrm{C}$ ). The samples were set at $100 \mu \mathrm{L}$ with nuclease-free water and stored at $20{ }^{\circ} \mathrm{C}$ until further use.

\section{Real-time quantitative PCR}

Carp-specific primers $\left(5^{\prime}-3^{\prime}\right)$ were used for detection of immune-related (inos, il-1 $\beta$, il-12p35, cxcl8_ll, cxcl8_12, cxcb1, cxcb2, cxcr1-3, c3, crp1, crp2, il-10, arginase 1, arginase 2, mmp9, cyr61, inhba, tgm2) and endocrine-related (er, er $\beta$, gpr30, cyp19a, cyp19b, vitellogenin) genes. The $40 \mathrm{~S}$ ribosomal protein s11 $(40 s 11)$ gene served as an internal standard. Accession numbers and primer sequences are listed in Table 1.

For RQ-PCR, $4 \mu \mathrm{L}$ cDNA and forward and reverse primers $(2 \mu \mathrm{L}$ each) were added to $7 \mu \mathrm{L}$ SYBR $®$ Select Master Mix (Applied Biosystems, Waltham, MA, 
Table 1 Primers used for quantitative real-time PCR analysis

\begin{tabular}{|c|c|c|c|c|}
\hline Gene & Primer forward $\left(5^{\prime}-3^{\prime}\right)$ & Primer reverse $\left(5^{\prime}-3^{\prime}\right)$ & Acc. no. & $\mu \mathrm{M}$ \\
\hline $40 s 11$ & CCGTGGGTGACATCGTTACA & TCAGGACATTGAACCTCACTGTCT & AB012087 & 1 \\
\hline inos & AACAGGTCTGAAAGGGAATCCA & CATTATCTCTCATGTCCAGAGTCTCTTCT & AJ242906 & 1 \\
\hline$i l-1 \beta$ & AAGGAGGCCAGTGGCTCTGT & CCTGAAGAAGAGGAGGCTGTCA & AJ245635 & 1 \\
\hline il-12p35 & TGCTTCTCTGTCTCTGTGATGGA & CACAGCTGCAGTCGTTCTTGA & AJ480354 & 1 \\
\hline cxcl8_ll & CTGGGATTCCTGACCATTGGT & GTTGGCTCTCTGTTTCAATGCA & AJ421443 & 1.125 \\
\hline cxcl8_l2 & TCACTTCACTGGTGTTGCTC & GGAATTGCTGGCTCTGAATG & AB470924 & 1.125 \\
\hline$c x c b 1$ & GGGCAGGTGTTTTTGTGTTGA & AAGAGCGACTTGCGGGTATG & AB082985 & 1.125 \\
\hline$c x c b 2$ & AGGCAGGTGCTTCTGTGCTGACA & TTCATGCATTTCCGCTCTGCGCT & JN104598 & 1.125 \\
\hline cxcrl & GCAAATTGGTTAGCCTGGTGA & AGGCGACTCCACTGCACAA & AB010468 & 1.125 \\
\hline cxcr 2 & TATGTGCAAACTGATTTCAGGCTTAC & GCACACACTATACCAACCAGATGG & AB010713 & 1.125 \\
\hline cxcr3 & TGTCAATGACCCCAAGCATCTGC & CACTCTGTCACGCCACTCGTAGG & HE584636 & 1.125 \\
\hline arginase 1 & TGAGGAGCTTCAGCGGATTAC & CCTATTATTCCCACGCAGTGATG & AJ871264 & 1 \\
\hline arginase 2 & GGAGACCTGGCCTTCAAGCATCT & CTGATTGGCACGTCCAACT & AJ618955 & 1 \\
\hline il-10 & CGCCAGCATAAAGAACTCGT & TGCCAAATACTGCTCGATGT & AB110780 & 1 \\
\hline mmp9 & ATGGGAAAGATGGACTGCTG & TCAAACAGGAAGGGGAAGTG & AB057407 & 2.25 \\
\hline cyr61 & AGTAGTCGGCTGCGTC & AATGCGGTTGTCATCATC & XM_019079046.1 & 2 \\
\hline inhba & TCCATCAAAGTCCAGCCTCT & CACCCTCACTGTCACCTTCC & XM_019110494.1 & 1 \\
\hline $\operatorname{tgm} 2$ & GCCTGGTATTTTGGACAGT & GCACTCAGCACTCTTGT & XM_019104041.1 & 1 \\
\hline vitellogenin & TGAAATTCTTCAGACCCCCATT & CATGGCCACATTGTTTGCA & AF414432.1 & 2 \\
\hline$c 3$ & GGTTATCAAGGGGAGTTGAGCTAT & TGCTGCTTTGGGTGGATGGGT & AB016215 & 1 \\
\hline crpl & AGCAATGCAACATTTTTCCGTC & ACTTGCGTCAAAGCCACCCAC & JQ010977 & 2 \\
\hline $\operatorname{crp} 2$ & GATGCTGCAGCATTTTTCAGTC & CTCCGCATCAAAGTTGCTCAAAT & JQ010978 & 2 \\
\hline er $\alpha$ & ACTGCCCACAAACTCTCACC & TGGGAACTCATAGGCTCCAT & BAF99812.1 & 1 \\
\hline $\operatorname{er} \beta$ & CCAGGTCCATTTGTTGGAGT & TGAGGTCTGGGGAGAAAATG & BAB91218.1 & 1 \\
\hline gpr30 & CGACTCTGCTTCCTTTCACC & GATCGTCACCTCAAGCCATT & XM_019067213.1 & 1 \\
\hline cyp19a & GGTGCCCAAGACAATGTATATGG & TTGTCCGATGGTGTCTGATGG & DQ534411.1 & 1 \\
\hline cyp $19 b$ & ATGATGGAGCAGGTCGTCAAG & TCAACGCCATCAACGTTACC & EU375456.1 & 1 \\
\hline
\end{tabular}

USA). RQ-PCR $\left(2 \mathrm{~min}\right.$ at $50{ }^{\circ} \mathrm{C}, 2 \mathrm{~min}$ at $95{ }^{\circ} \mathrm{C}, 40$ cycles of $15 \mathrm{~s}$ at $95{ }^{\circ} \mathrm{C}, 60 \mathrm{~s}$ at $60^{\circ} \mathrm{C}$ ) was carried out with a Rotor-Gene Q (Qiagen, Hilden, Germany). Following each run, melt curves were collected by detecting fluorescence from 60 to $90{ }^{\circ} \mathrm{C}$ at $1{ }^{\circ} \mathrm{C}$ intervals.

Constitutive expression was rendered as a ratio of target gene vs. reference gene (40S ribosomal protein s11 gene) and was calculated according to the following equation:

ratio $=\frac{\left(E_{\text {reference }}\right)^{C t_{\text {reference }}}}{\left(E_{\text {target }}\right)^{C t_{\text {target }}}}$

Changes in gene expression upon E2 treatment and/ or cell stimulation were rendered as a ratio of target gene vs. reference gene (40S ribosomal protein s11 gene) relative to their expression in control samples according to the following equation:

ratio $=\frac{\left(E_{\text {target }}\right)^{\Delta C t} \text { target }^{(\text {control-sample })}}{\left(E_{\text {reference }}\right)^{\Delta C t} \text { reference }^{(\text {control-sample })}}$

where $E$ is the amplification efficiency and $C t$ is the number of PCR cycles needed for the signal to exceed a predetermined threshold value (Pfaffl 2001).

Statistical analysis

Data were expressed as mean and standard error (S.E.). Bartlett's test was performed to ensure the suitability of the data for parametric significance tests. Significant differences between infected groups were assessed by 
one-way ANOVA followed by post hoc Tukey's test in case of normally distributed data, or with the nonparametric Kruskal-Wallis test followed by Dunn's test for data that were not normally distributed. The differences were considered statistically significant at $p<0.05$.

\section{Results}

In vitro effects of E2

Consistent with previous research, in monocytes/ macrophages in vitro, LPS stimulated gene expression of pro-inflammatory mediators: inos, il-1 $\beta$, il12p35, cxcl8_l1, cxcl8_l2, and cxcb2) (Fig. 1 and Table 1S) as well as anti-inflammatory: arginase 1, arginase 2, il-10, and cyr61, inhba, and tgm2 (Fig. 2 and Table 1S).

E2 alone downregulated gene expression of inos, cxcb2, cxcr1, cxcr2 (Fig. 1 and Table 1S), and mmp9 (Fig. 2d and Table 1S).

LPS + E2-treated cells showed a downregulated gene expression of inos, il-1 $\beta$, il-12p35, cxcb2, and cxcr2 (Fig. 1 and Table 1S) as well as arginase 1 and 2, il10, mmp9, cyr61, inhba, and tgm2 (Fig. 2 and Table 1S) compared to cells treated with LPS only.

Only the $\mathrm{cxcl}$ \& $l 1$ gene expression was synergistically upregulated upon treatment with LPS + E2 (Fig. 1d and Table 1S).

Moreover, upon in vitro LPS treatment, increased levels of NO were found in supernatants from monocytes/macrophages, while E2 did not change the NO production in unstimulated nor in LPS-stimulated cells. Moreover, neither LPS nor E2 affected the activity of arginase (Fig. 3).

In monocytes/macrophages in vitro, LPS decreased the gene expression of er $\alpha$ and $\operatorname{er} \beta$ (Fig. $4 \mathrm{a}, \mathrm{b}$ and Table 1S), while both E2 and LPS + E2 did not affect the expression of the er $\alpha, \operatorname{er} \beta$, gpr 30 , and cyp 19 genes in these cells (Fig. 4 and Table 1S).

In vivo effects of $\mathrm{E} 2$

\section{Level of hormone and vitellogenin gene expression}

In fish fed with E2-treated food, both at 24 and $96 \mathrm{hpi}$, a significantly higher level of E2 was found in blood serum and an upregulation of the vitellogenin gene expression was observed in the liver, compared to the levels in animals fed with non-E2 food (Fig. 5 and Table 2S). The level of E2 in E2-treated fish was higher at 24 hpi than at 96 hpi (Fig. 5a).

\section{Number and composition of inflammatory leukocytes}

In control fish, the total number of peritoneal leukocytes (Fig. 6a) and from these the number of phagocytic cells (Fig. 6b) and lymphocytes (Fig. 6c) were lower at 96 hpi than at 24 hpi. At 24 hpi, E2 decreased the total number of peritoneal leukocytes (Fig. 6a) and the number of phagocytes (Fig. 6b).

\section{Gene expression of pro- and anti-inflammatory} mediators

At $24 \mathrm{hpi}$, a significantly higher gene expression of proinflammatory $i l-12 p 35$ and $c x c b 2$ as well as antiinflammatory arginase 1 and 2, il-10, and $m m p 9$ was observed in the head kidney of E2-treated fish than in fish fed with control (non-E2) food (Figs. 7 and 8 and Table 2S).

At 96 hpi, gene expression of pro- and antiinflammatory mediators was similar in E2- and nonE2-fed fish. In E2-treated fish, the expression of il12p35, cxcb2, arginase 1 and 2, il-10, and mmp9 was lower at 96 hpi than at 24 hpi (Figs. 7 and 8 and Table 2S).

At 24 hpi, E2 treatment did not affect the gene expression of pro- and anti-inflammatory mediators in the peritoneal leukocytes while at $96 \mathrm{hpi}$, it upregulated the expression of the $i l-10$ gene (Table 2 and $2 \mathrm{~S}$ ).

At 96 hpi, E2 decreased in the liver expression of inos while it downregulated the liver expression of crp2 at both at 24 and 96 hpi compared to control animals (Table 3 and 2S).

\section{Gene expression of estrogen receptors and Cyp19 aromatase}

In the head kidney, E2 treatment upregulated the gene expression of the estrogen receptors (er $\alpha$, er $\beta$, gpr 30$)$ and of the aromatase (cyp19a and cyp19b) genes at 24 hpi (Fig. 9 and Table 2S). At the same point in the liver of E2-fed animals, the expression of the gpr30 and cyp $19 a$ genes was lower than in animals fed with control food (Table 4 and Table 2S). Both at 24 and 96 hpi, E2 upregulated the expression of the er $\alpha$ gene in this organ. 

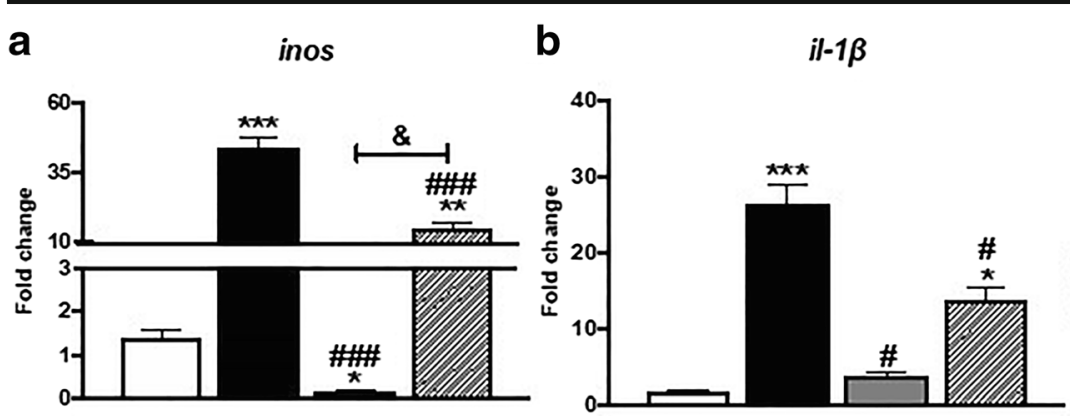

C $\quad$ it $12 \mathrm{p} 35$

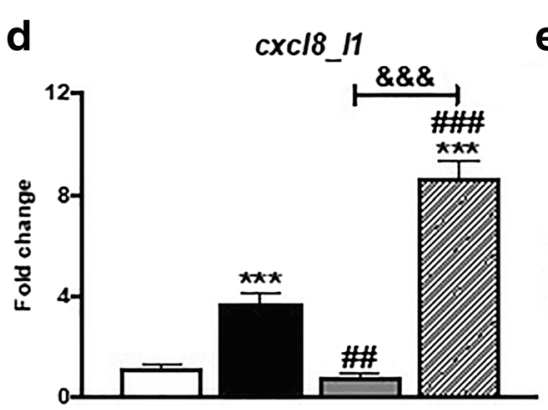

e cxc/8_12
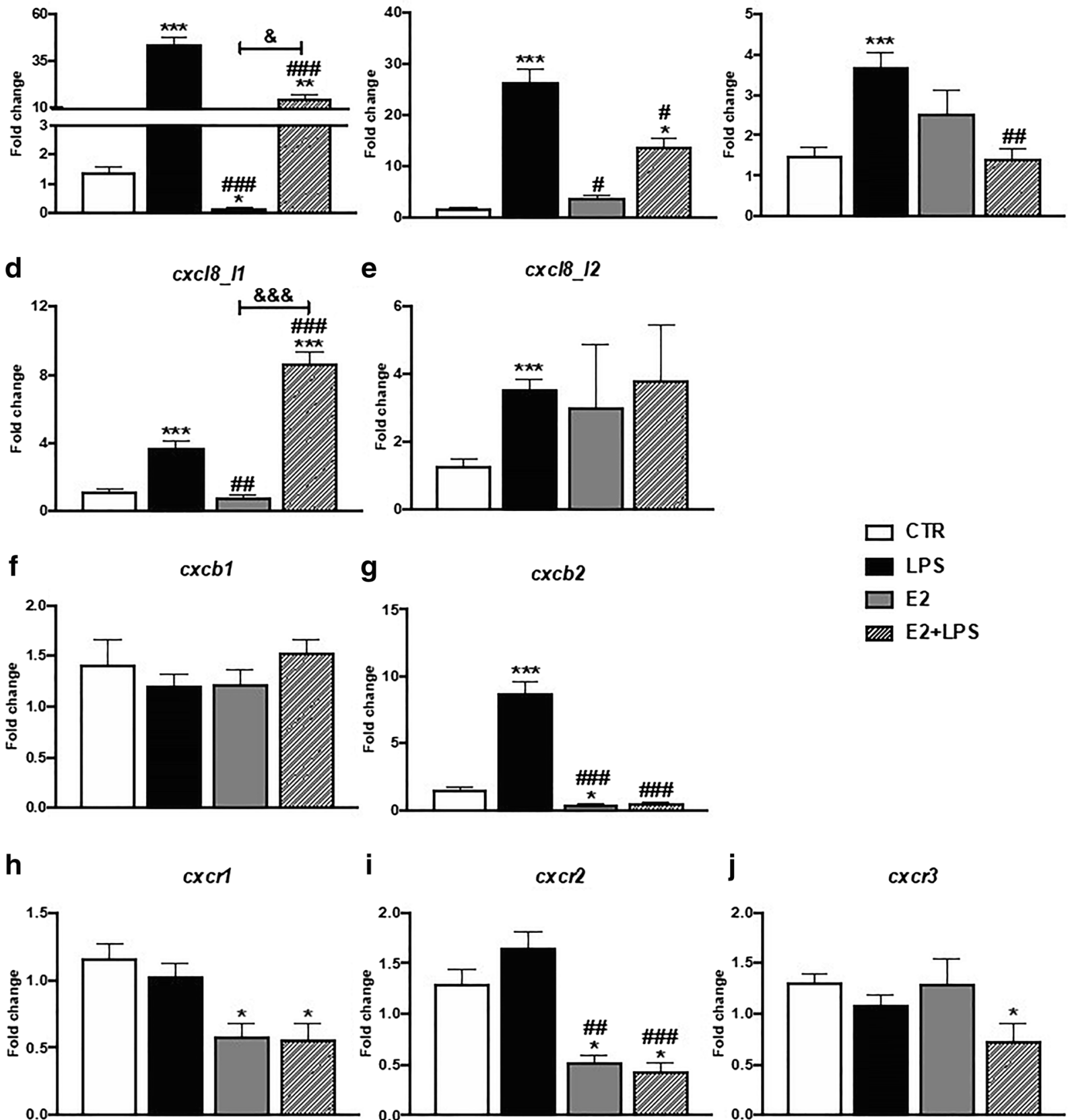

cxcr2

j

cxcr3
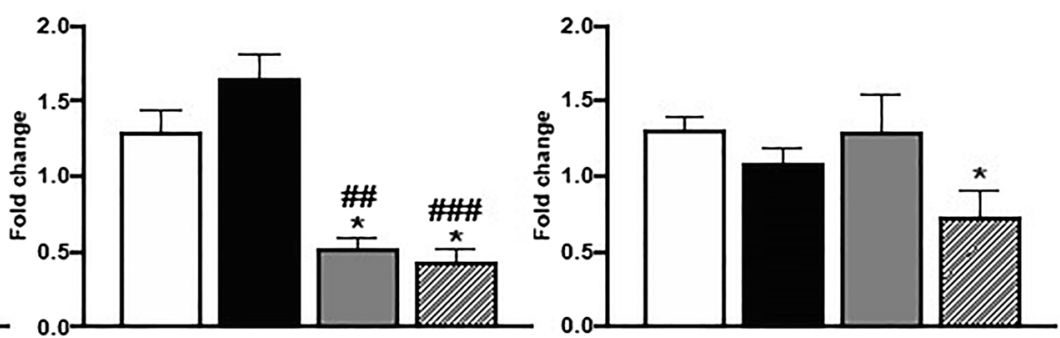

Fig. 1 In vitro effects of $17 \beta$-estradiol on the gene expression of pro-inflammatory mediators $(\mathbf{a}-\mathbf{c})$, CXC chemokines $(\mathbf{d}-\mathbf{g})$, and their receptors $(\mathbf{h}-\mathbf{j})$ in the head kidney monocytes/macrophages. Cells were in vitro treated for $6 \mathrm{~h}$ with lipopolysaccharide (LPS, $30 \mu \mathrm{g} / \mathrm{mL}), 17 \beta$-estradiol (E2, $1 \mu \mathrm{M})$, or their combination (E2 + LPS). Changes in gene expression are shown as $x$-fold increase compared to unstimulated, treated with culture medium cells (CTR), and they were standardized for the housekeeping gene
40S ribosomal protein s11. Averages and S.E. $(n=4-5)$. Stars (*) indicate statistically significant differences between control (CTR) and treated cells (E2, LPS, and E2 + LPS) $(* p \leq 0.05$, $* * p \leq 0.001, * * * p \leq 0.0001)$, number signs (\#) indicate statistically significant differences between LPS-treated cells (LPS) and E2or E2 + LPS-treated cells ( $\# p \leq 0.05$, \#\#p $\leq 0.001$, \#\#\# $\leq 0.0001)$, and ampersands $(\&)$ indicate statistically significant differences between E2- and E2 + LPS-treated cells $(\& p \leq 0.05)$ 


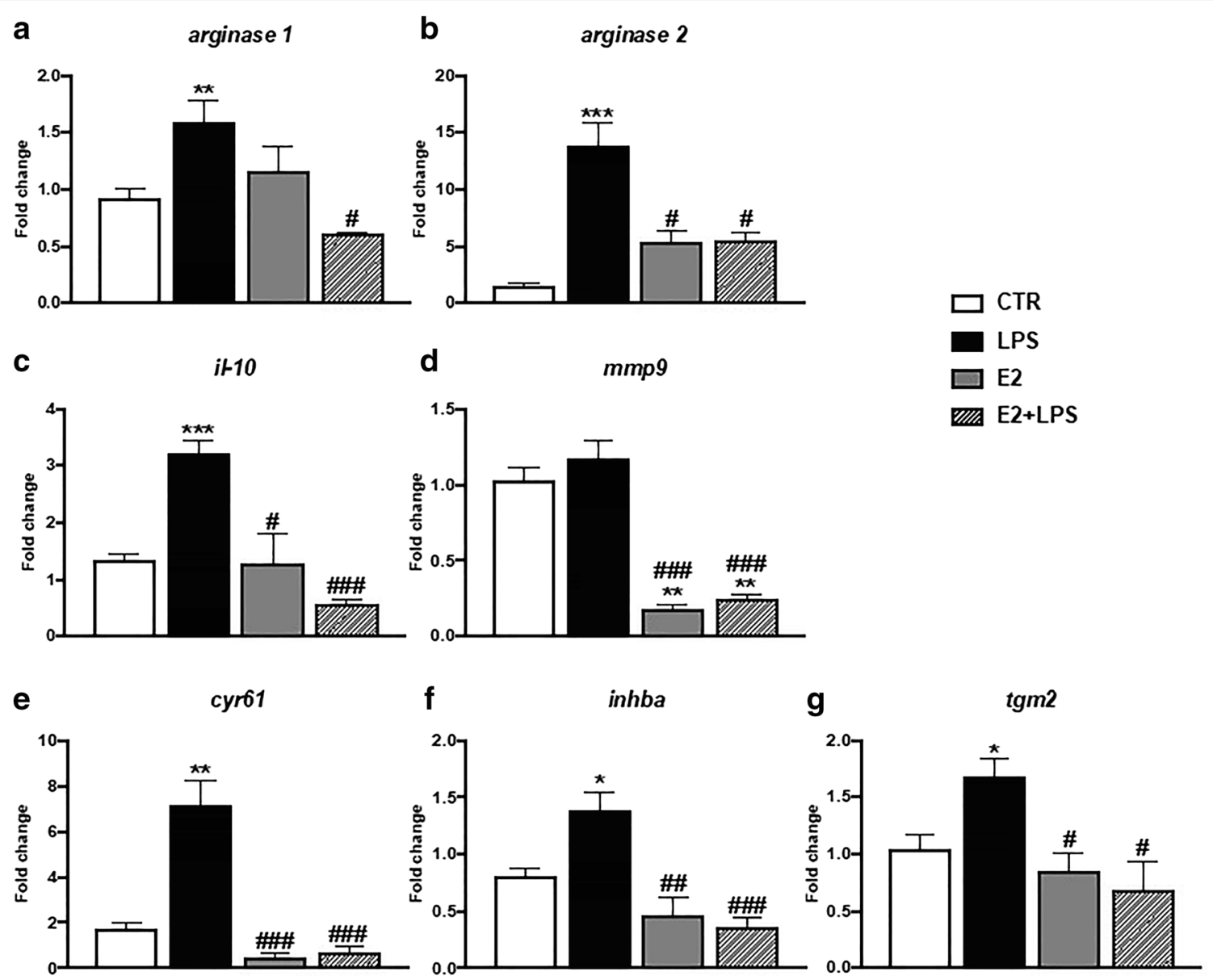

Fig. 2 In vitro effects of $17 \beta$-estradiol on the gene expression of anti-inflammatory mediators in the head kidney monocytes/macrophages. Cells were in vitro treated for $6 \mathrm{~h}$ with lipopolysaccharide (LPS, $30 \mu \mathrm{g} / \mathrm{mL}), 17 \beta$-estradiol $(\mathrm{E} 2,1 \mu \mathrm{M})$, or their combination (E2 + LPS). Changes in gene expression are shown as $x$ fold increase compared unstimulated, treated with culture medium cells (CTR) and were standardized for the housekeeping gene 40S

At 24 hpi, E2 treatment did not affect the gene expression of estrogen receptors and aromatase cyp $19 a$ and cyp $19 b$ in peritoneal leukocytes (Table 4 and 2S). An upregulation of the expression of cyp $19 \mathrm{~b}$ was observed in the peritoneal leukocytes (Table 4 and 2S).

\section{Discussion}

In the present study, we focused on the in vitro and in vivo effects of $17 \beta$-estradiol on the innate immune response against bacterial infection in common carp. ribosomal protein s11. Averages and S.E. $(n=4-5)$. Stars $(*)$ indicate statistically significant differences between control (CTR) and treated cells (E2, LPS, and E2 + LPS) $(* p \leq 0.05$, $* * p \leq 0.001, * * * \mathrm{p} \leq 0.0001)$, number signs (\#) indicate statistically significant differences between LPS-treated cells (LPS) and E2or E2 + LPS-treated cells (\#p $\leq 0.05, \# \# p \leq 0.001$, \#\#\# $\leq 0.0001)$

E2 in vitro decreases the LPS-induced activation of monocytes/macrophages

We found that in vitro in monocytes/macrophages E2 alone reduced the gene expression of the proinflammatory inos, cxcb2, and chemokine receptors cxcr1-2. Moreover, E2 in combination with LPS reduced the LPS-induced effects by decreasing the gene expression of pro-inflammatory mediators: inos, il-1 $\beta$, $i l-12 p 35, c x c b 2$, and chemokine receptor $c x c r 2$. These data suggest that during bacterial stimulation, E2 downregulates the cellular immune response. A similar pattern of response, indicating changes in IFN- $\gamma$ dependent cellular immune response, was also found 
a Nitric oxide

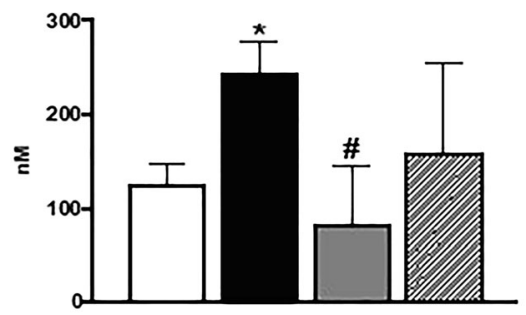

b

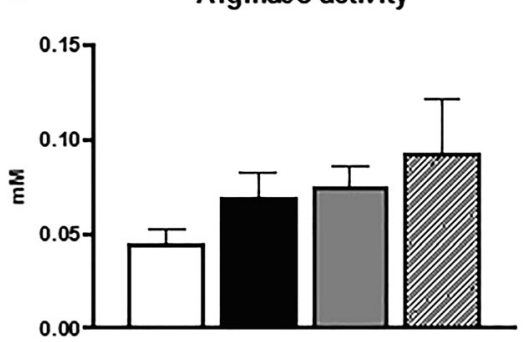

Fig. 3 In vitro effects of $17 \beta$-estradiol on the production of nitric oxide (a) and on the arginase activity (b) in the head kidney monocytes/macrophages. Cells were in vitro treated for $24 \mathrm{~h}$ with either lipopolysaccharide (LPS, $30 \mu \mathrm{g} / \mathrm{mL}$ ) or $17 \beta$-estradiol (E2, $1 \mu \mathrm{M}$ ) or their combination (E2 + LPS) or were treated with culture medium (CTR). Averages and S.E. $(n=4-5)$. Stars $(*)$ indicate statistically significant differences between control (CTR) and treated cells (E2, LPS, and E2 + LPS) $(* p \leq 0.05)$, number signs (\#) indicate statistically significant differences between LPS-treated cells (LPS) and E2- or E2 + LPS-treated cells (\#p $\leq 0.05)$

in our recent experiment with carp monocytes/ macrophages that were treated in vitro with proestrogenic endocrine-disrupting compounds (EDCs) such as $17 \alpha$-ethynylestradiol (EE2) and 4-tertoctyphenol (Maciuszek et al., submitted).

Similarly, in vitro studies with the murine RAW264.7 macrophage cell line have shown that estradiol via $\mathrm{ER} \alpha$ abolished the LPS-induced changes in early pro-inflammatory gene expression by avoiding intracellular NFKB transport without altering the IKK pathway (Ghisletti et al. 2005). Interestingly, E2 also reduced the LPS-induced expression of mediators that are involved in the resolution of inflammation, in angiogenesis, and in the process of wound healing/tissue repair such as arginase 1 and 2, il-10, $\mathrm{mmp} 9$, cyr61, inhba, and tgm2 (Jaźwińska et al. 2007; Chadzinska et al. 2008a, b; Campbell et al. 2013; LeBert et al. 2015; Godwin et al. 2017; Hodgkinson et al. 2017; Hui et al. 2017; Costa and Power 2018). Previous studies on murine bone marrow-derived macrophages (BMDMs) also showed that pre-treatment with E2 decreased the LPS + INF- $\gamma$-induced inos expression whereas it did not affect the gene expression of arginase 1 (Campbell et al. 2014). In the same study, E2 did not change inos and arginase 1 gene expression in IL-4treated M2 macrophages. Moreover, the authors showed that the polarization of macrophages towards both the $\mathrm{M} 1$ and $\mathrm{M} 2$ phenotype passes via the $\mathrm{ER} \alpha$ receptor and the lack of ER $\alpha$ in the macrophages prevents M2 polarization (Campbell et al. 2014). Similarly, Villa et al. (2015) found that in RAW 264.7 macrophages, E2 facilitated a progression of the inflammatory process towards the IL10-dependent "acquired deactivation" phenotype, which is responsible for tissue remodeling and the restoration of homeostatic conditions. This process takes place through regulation of the Socs3 and Stat3 signaling pathways. In contrast, Yang et al. (2012) found that, in vitro, E2 inhibited the alternative polarization of IL-4-stimulated tumor-associated ANA1 macrophages. It reduced the arginase activity and the expression of CD206, and its action was associated with an inhibition of phosphorylation of the Jak1-Stat6 molecules and damage of the ER $\beta$ and ATPase interaction.

Also, in fish, data concerning the effects of E2 are often contradictory. For example, Yamaguchi et al. (2001) showed that E2 in vitro increased the phagocytic activity but did not change the NO and ROS production in carp macrophages. Conversely, in a goldfish macrophage cell line, E2 stimulation did not affect NO production but decreased phagocytosis (Wang and Belosevic 1995). Moreover, an immunomodulatory role of E2 was observed in gilthead seabream where it in vitro increased the expression of pro-inflammatory cytokines, chemokines, and toll-like receptor (TLR) genes as well as gene expression of tissue remodeling molecules, e.g., MMP13, in both naïve and Vibrio anguillarum genomic DNA (VaDNA)-stimulated macrophages. Furthermore, E2-treated seabream macrophages showed decreased phagocytosis, while no effects were observed on their ROS production or cell migration (Liarte et al. 2011b). In contrast, in adherent anterior leukocytes of channel catfish, bactericidal and ROS activity decreased upon E2 treatment (Iwanowicz et al. 2014). Moreover, recently, Paiola et al. (2019) found that in sea bass, E2 modulated redox biology and viability of myeloid cells in vitro in a dose- and time-dependent fashion. Also, cells of different origins (thymus, spleen, or head kidney leukocytes) showed a different response. In turn, our previous studies showed 

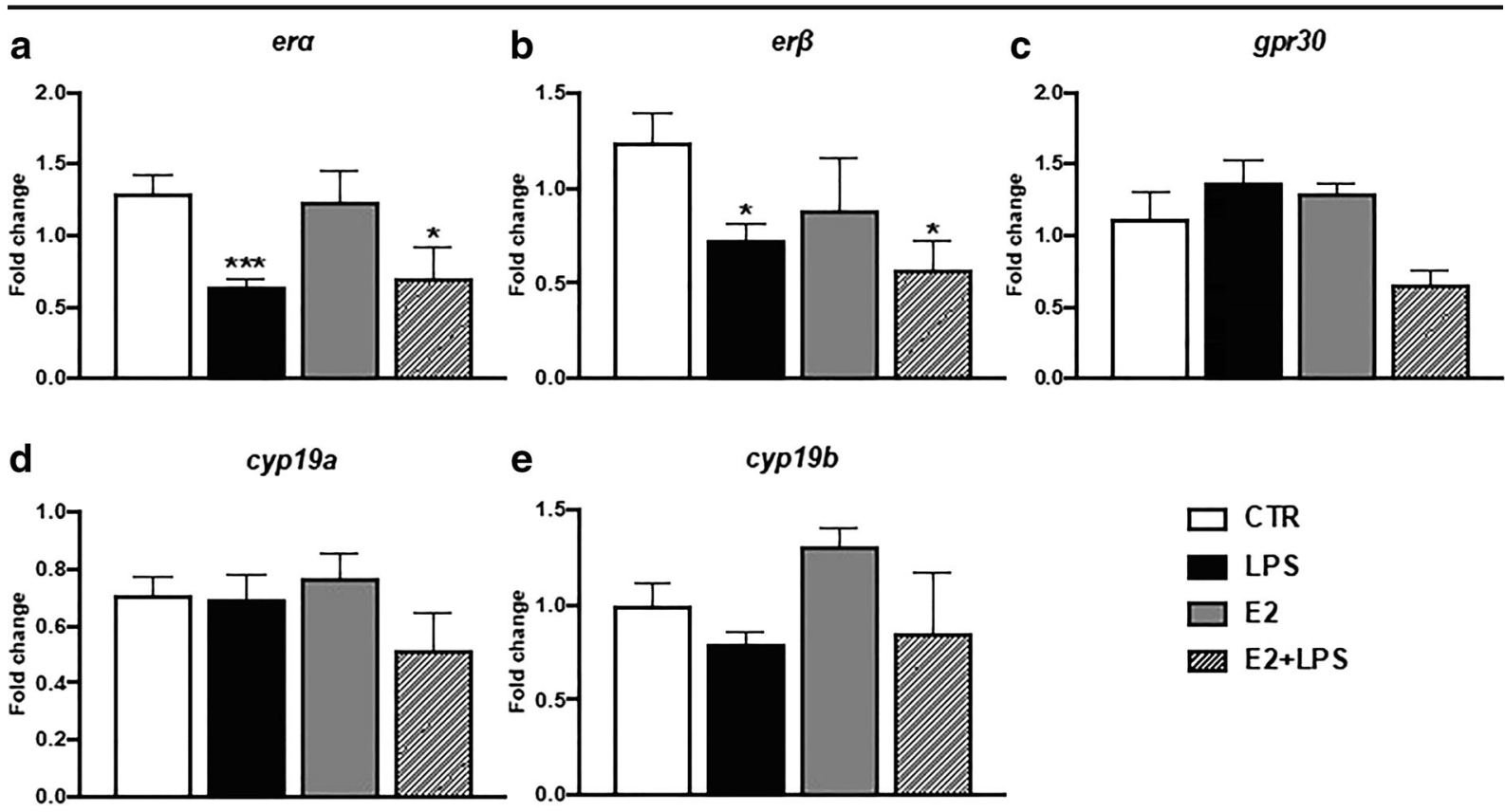

Fig. 4 In vitro effects of $17 \beta$-estradiol on the gene expression of estrogen receptors $(\mathbf{a}-\mathbf{c})$ and aromatase CYP19 $(\mathbf{d}-\mathbf{e})$ in the head kidney monocytes/macrophages. Cells were in vitro treated for $6 \mathrm{~h}$ with lipopolysaccharide (LPS, $30 \mu \mathrm{g} / \mathrm{mL}$ ), $17 \beta$-estradiol (E2, $1 \mu \mathrm{M}$ ), or their combination (E2 + LPS). Changes in gene expression are shown as $x$-fold increase compared to unstimulated, treated with culture medium, cells (CTR) and were standardized for the housekeeping gene $40 \mathrm{~S}$ ribosomal protein s11. Averages and S.E. $(n=4-5)$. Stars $(*)$ indicate statistically significant differences between control (CTR) and treated cells (E2, LPS, and $\mathrm{E} 2+\mathrm{LPS})(* p \leq 0.05, * * * p \leq 0.0001)$

fish, E2, alone or combined with bacterial DNA, was able to upregulate the expression of CXCL8 in gilthead seabream endothelial cells and macrophages (Liarte et al. 2011a, b)

It is intriguing that in the present study, E2 did not increase the in vitro expression of estrogen receptors or aromatase, whereas cell stimulation with LPS alone caused a decrease in $\operatorname{er} \alpha$ and $\operatorname{er} \beta$ expression. Similarly, LPS stimulation downregulated the expression of er $\alpha 1$ and 2 in rainbow trout peripheral blood leukocytes (Shelley et al. 2012). In turn, in gilthead seabream macrophages, stimulation with VaDNA increased the gene expression of er $\alpha$, er $\beta 1$, and er $\beta 2$ (Liarte et al. 2011b). Our results support the hypothesis that in this way, the immune system changes the sensitivity to estradiol during inflammation. Moreover, Iwanowicz et al. (2014) found that ER gene expression was regulated in peripheral blood leukocytes of channel catfish following activation with concanavalin A and lipopolysaccharide. Also, in mammals, an LPS-induced downregulation of ER expression was observed in the RAW264.7 cell line, in microglial and in 


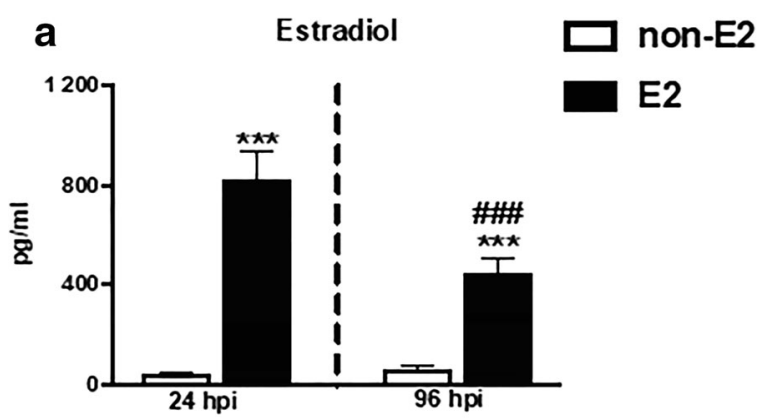

b

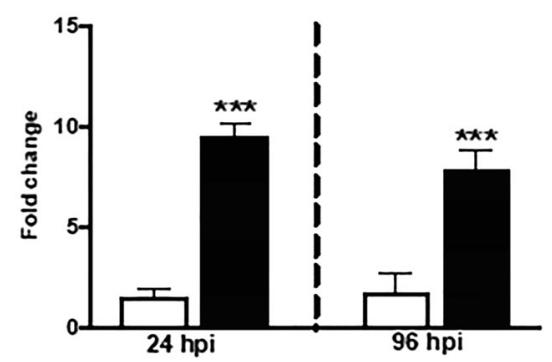

Fig. 5 In vivo effects on the level of $17 \beta$-estradiol in blood plasma (a) and gene expression of vitellogenin in liver (b). Fish were fed for 14 days with control food (non-E2) or food treated with $17 \beta$-estradiol (E2, $20 \mathrm{mg} / \mathrm{kg}$ food). On day $14 \mathrm{ofE} 2$ feeding, fish were injected i.p. with $A$. salmonicida $\left(4 \times 10^{8}\right.$ bacteria in $250 \mu \mathrm{L}$ PBS per fish). At 24 and $96 \mathrm{~h}$ post-infection (hpi), the blood (to measure E2 level) and livers (to measure vitellogenin gene expression) were collected. Averages and S.E. $(n=7)$. Changes in gene expression are shown as $x$-fold increase compared to the control group (CTR) and standardized for the housekeeping gene 40 S ribosomal protein s11. Stars (*) indicate statistically significant differences between control (CTR) and E2treated animals $(* * * p \leq 0.0001)$; number signs (\#) indicate statistically significant differences between time points of infection (24 vs 96 hpi) (\#\#\#p $\leq 0.0001)$ endothelin cells (Vegeto et al. 2004; Sierra et al. 2008; Holm et al. 2010).

E2-induced changes in the expression of estrogen receptors in mammalian and fish leukocytes are often contradictory. For example, Rastgar et al. (2019) found that long-term (3 days) incubation with E2 increased expression of er $\alpha$, er $\beta 1$, and er $\beta 2$ in cultured goldfish macrophages, while it was unaffected by 4-day incubation with E2 in rainbow trout peripheral blood leukocytes stimulated with LPS (Shelley et al. 2013)

In vivo $\mathrm{E} 2$ treatment downregulates inflammatory response induced by $A$. salmonicida infection

Following the in vitro studies, where E2 suppressed the activity of LPS-stimulated monocytes/macrophages, we wanted to verify the effects of this estrogen on the antibacterial innate immune response in vivo. In this experiment, in animals fed with E2-treated food, a lower number of inflammatory phagocytes (monocytes/macrophages and neutrophilic granulocytes) was found in the peritoneum at $24 \mathrm{~h}$ post $A$. salmonicida i.p. injection. This suggests that in animals with increased E2 levels, the inflammatory reaction, manifested by leukocyte influx to the infection site, was weaker. Moreover, the anti-inflammatory action of E2 is corroborated by the slight but significant upregulation of the expression of anti-inflammatory $\mathrm{il}-10$ in peritoneal leukocytes at 96 hpi. Simultaneously, both at 24 and 96 hpi, E2 downregulated the gene expression of C-reactive protein in the liver, which supports the hypothesized antiinflammatory action of E2. The elevated expression of both pro- (il-12p35 and cxcb2) and anti-inflammatory a

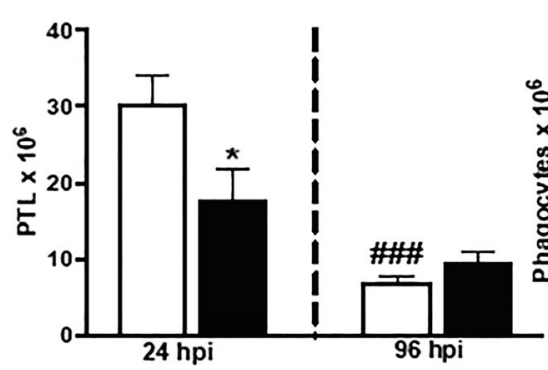

b

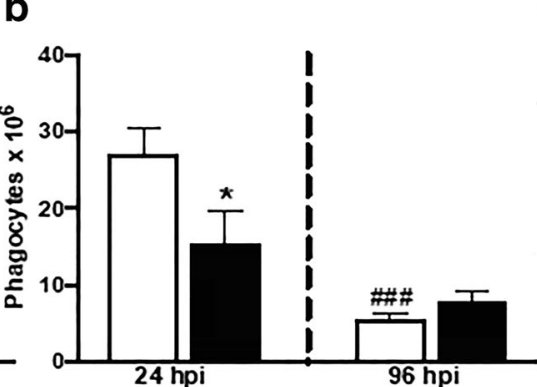

C

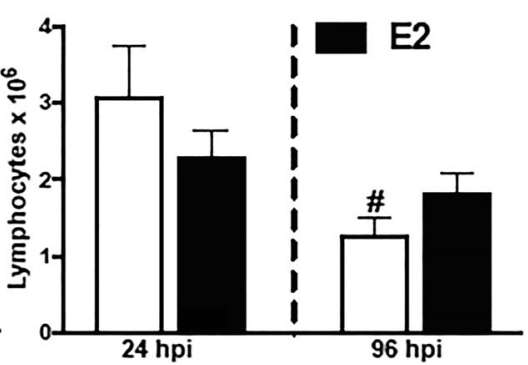

Fig. 6 In vivo effects of $17 \beta$-estradiol on the number and composition of peritoneal leukocytes. Fish were fed for 14 days with control food (non-E2) or food treated with $17 \beta$-estradiol (E2, $20 \mathrm{mg} / \mathrm{kg}$ food). On day 14 of E2 feeding, fish were injected i.p. with A. salmonicida $\left(4 \times 10^{8}\right.$ bacteria in $250 \mu \mathrm{L}$ PBS per fish). At 24 and $96 \mathrm{~h}$ post-infection (hpi), peritoneal leukocytes (PTL) were collected and their number and composition (number of phagocytes and lymphocyte) were analyzed. Averages and S.E. $(n=7)$. Stars $(*)$ indicate statistically significant differences between control (CTR) and E2-treated animals $(* p \leq 0.05)$; number signs (\#) indicate statistically significant differences between time points of infection (24 vs 96 hpi) $(\# p \leq 0.05$, \#\#\# $\leq 0.0001)$ 
b
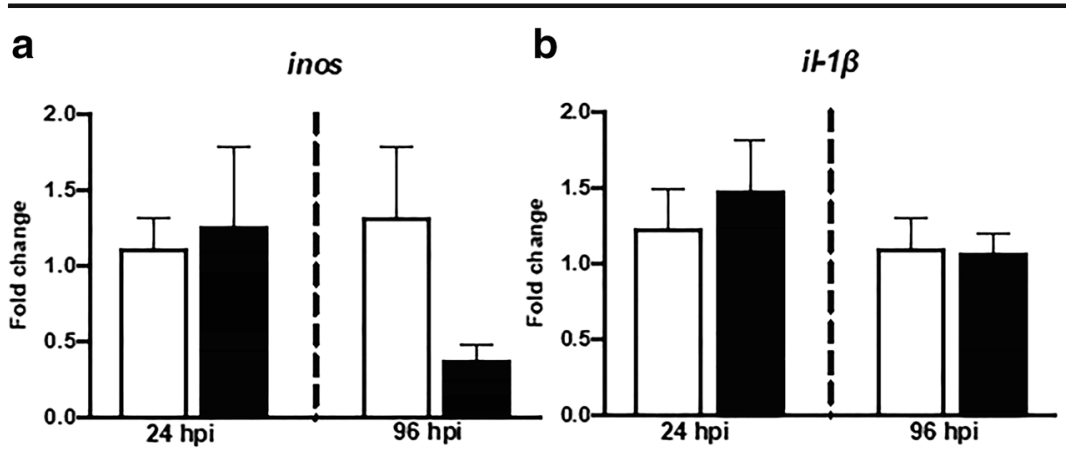

e

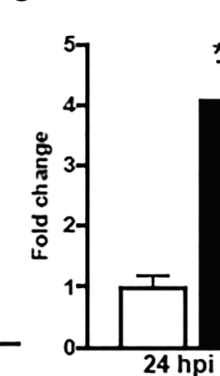

Fig. 7 In vivo effects of $17 \beta$-estradiol on the gene expression of pro-inflammatory mediators (a-c) and CXC chemokines $(\mathbf{d}-\mathbf{e})$ in the head kidney. Fish were fed for 14 days with control food (nonE2) or food treated with $17 \beta$-estradiol (E2, $20 \mathrm{mg} / \mathrm{kg}$ food). On day 14 of E2 feeding, fish were injected i.p. with A. salmonicida $\left(4 \times 10^{8}\right.$ bacteria in $250 \mu \mathrm{L}$ PBS per fish). At 24 and $96 \mathrm{~h}$ postinfection (hpi), the head kidneys were collected, and gene expression was measured. Changes in gene expression are shown as $x$ -

(arginase 1 and 2, il-10 and $\mathrm{mmp} 9$ ) at $24 \mathrm{hpi}$ in the head kidney reflects the importance of this organ as main source of inflammatory leukocytes in teleost fish (Gruca et al. 1996; Chadzinska et al. 2008b). Therefore, differences in the gene expression in the head kidney between control and E2-treated fish can be a consequence of E2-induced changes in the leukocyte emigration from the head kidney to the peritoneum, the latter being the focus of inflammation. Although in the present experiment E2 treatment did not induce any fish mortality, we cannot exclude that harmful effects could be revealed at later stages of the infection. Previously, Wenger et al. (2011) found that E2 increased fish mortality and decreased the expression of hepatic complement components (c3-1, c3-3, and factor-H) in Yersinia ruckeri-infected rainbow trout. In turn, an in vivo study of juvenile sea bass exposed to E2 (20 ng/L) showed a reduction in the gene expression of pro-inflammatory cytokines (il-1 $\beta$, tnf $\alpha$, il- 6$)$ in the head kidney, compared to control animals and fish exposed to high E2 concentration (200 ng/L) (Seemann et al. 2013). ir $1 \beta$

C il-12p35

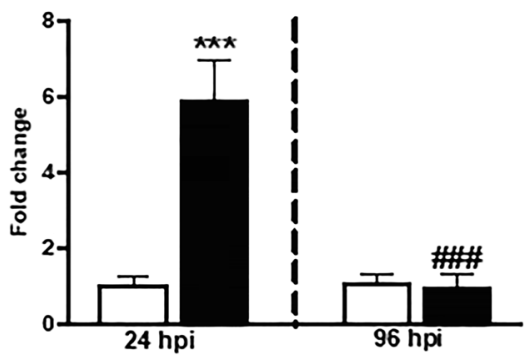

cxcb2

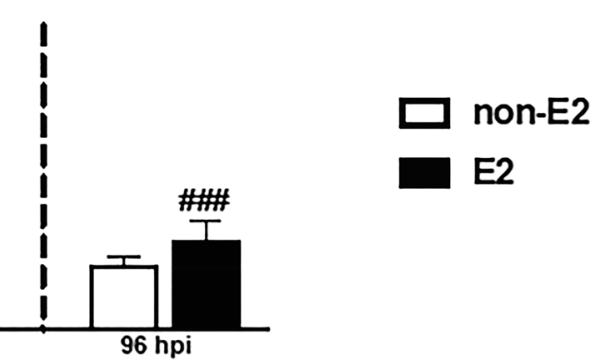

fold increase compared to control group (non-E2) and standardized for the housekeeping gene 40S ribosomal protein s11. Averages and S.E. $(n=7)$. Stars $(*)$ indicate statistically significant differences between control (CTR) and E2-treated animals $(* * * p \leq 0.0001)$, number signs (\#) indicate statistically significant differences between time points of infection ( 24 vs $96 \mathrm{hpi}$ ) (\#\#\# $\leq 0.0001)$

Furthermore, studies in rainbow trout showed no E2induced changes in the expression of $t n f \alpha, i l-1 \beta$, and cxcr 4 compared to the control group that was not treated with E2 (Shelley et al. 2013) while exposure of largemouth bass to E2 reduced in the liver constitutive gene expression of antimicrobial hepcidin 1 and blocked induced during Edwardsiella ictaluri infection expression of hepcidin-2 gene (Robertson et al. 2009).

In our opinion, the most striking changes upon in vivo E2 treatment concerned upregulation of gene expression of mediators involved in the resolution of inflammation and in tissue repair (both arginases, il10 and $\mathrm{mmp9)}$ at 24 hpi. Similarly, in mammals, during zymosan-induced peritonitis, E2 treatment promoted an anti-inflammatory and pro-resolving phenotype in zymosan-induced peritoneal macrophages, which correlated with the induction of genes involved in macrophage alternative activation and with IL-10 expression in vivo. E2 also accelerated wound healing, while reducing the influx of leukocytes to the site of inflammation (Emmerson et al. 


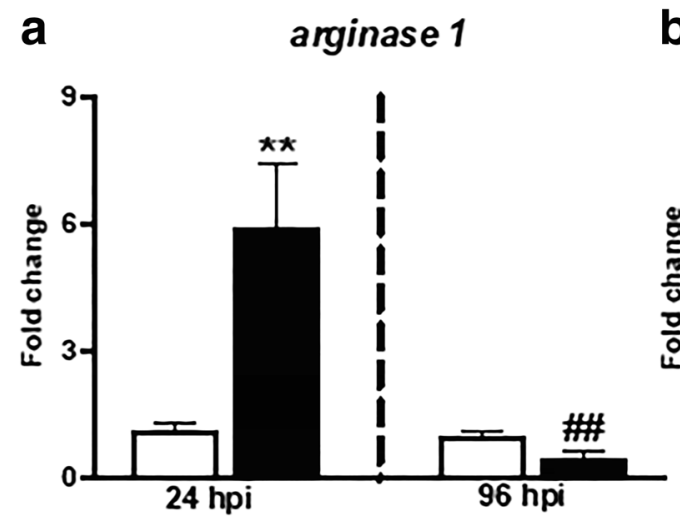

b arginase 2

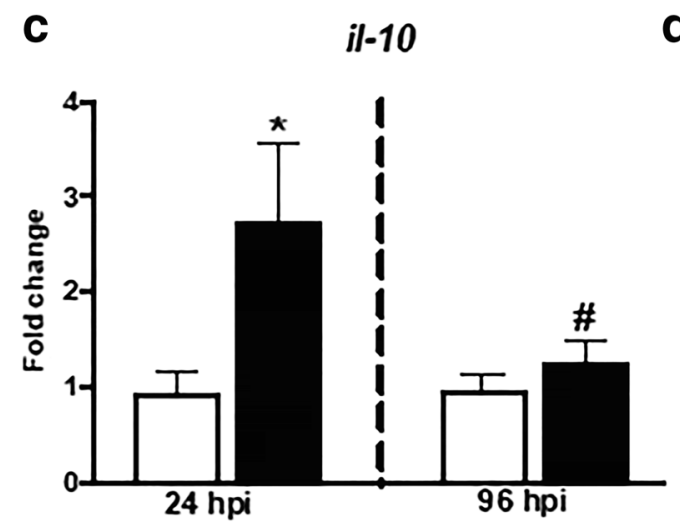

Fig. 8 In vivo effects of $17 \beta$-estradiol on the gene expression of anti-inflammatory mediators in the head kidney. Fish were fed for 14 days with control food (non-E2) or food treated with $17 \beta$ estradiol (E2, $20 \mathrm{mg} / \mathrm{kg}$ food). On day $14 \mathrm{of}$ 2 2 feeding, fish were injected i.p. with A. salmonicida $\left(4 \times 10^{8}\right.$ bacteria in $250 \mu \mathrm{L}$ PBS per fish). At 24 and $96 \mathrm{~h}$ post-infection (hpi), the head kidneys were collected, and gene expression was measured. Changes in

2009). Also, Campbell et al. (2010) found that the healing process is specifically dependent on estrogen receptor $\mathrm{ER} \alpha$. They observed that in mice with $\mathrm{ER} \alpha$ gene disruption, wound healing and alternative polarization were delayed. On the other hand, exogenous administration of E2 to WT mice reduced the area of wound healing and increased wound re-epithelialization. Similar results were obtained by Routley and Ashcroft (2009), suggesting that lower levels of steroid hormones (estrogen or progesterone) cause polarization towards M1 (increased $\operatorname{tnf} \alpha$ expression), while higher concentration of hormones shift polarization towards the M2 phenotype. Also, Ashcroft et al. (2003) found that estradiol accelerates wound healing by local inhibition of macrophage migration inhibitory factor (MIF).
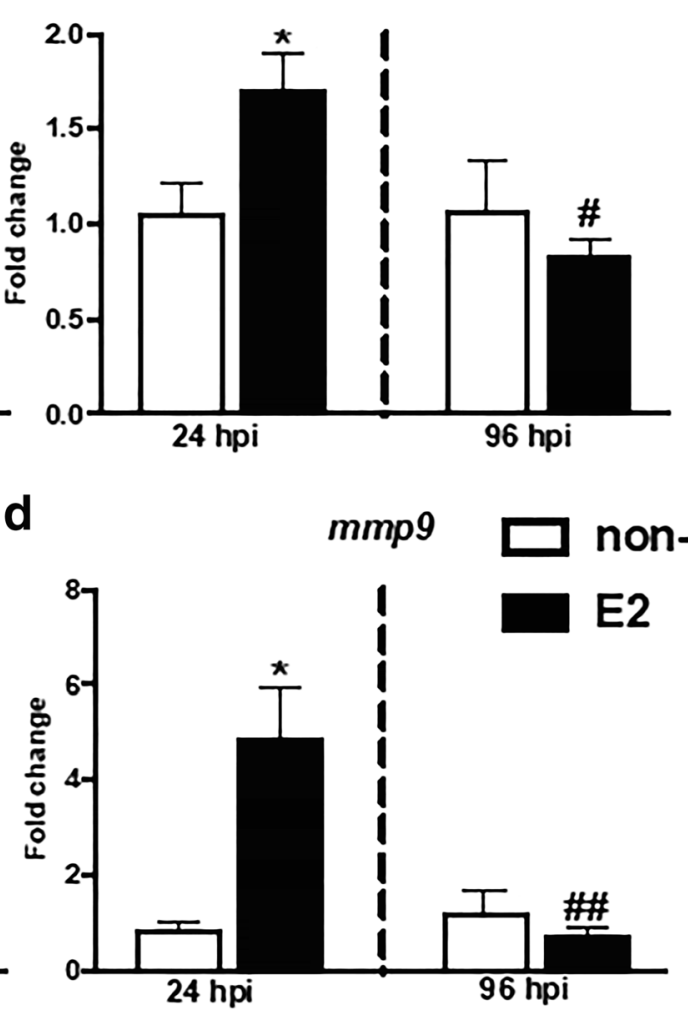

gene expression are shown as $x$-fold increase compared to control group (non-E2) and standardized for the housekeeping gene $40 \mathrm{~S}$ ribosomal protein s11. Averages and S.E. $(n=7)$. Stars $(*)$ indicate statistically significant differences between control (CTR) and E2treated animals $(* p \leq 0.05, * * p \leq 0.001)$; number signs (\#) indicate statistically significant differences between time points of infection (24 vs 96 hpi) $(\# p \leq 0.05, \# \# p \leq 0.001)$

So far, only limited studies, describing E2-induced changes in the expression of anti-inflammatory and wound healing markers, were published for teleost fish. For example, Seemann et al. (2013) found that estradiol did not affect the expression of $\operatorname{tg} f \beta$ in the head kidney or change the level of TGF $\beta$ protein in the blood of juvenile sea bass. In gilthead seabream, estradiol increased the activity of MMP2 and MMP9 in testicle leukocytes (Chaves-Pozo et al. 2018). It also accelerated wound repair after scale removal in gilthead sea bream possibly via ER $\beta$ s. In this study, the proteome of regenerating skin from E2-treated and control fish differed in keratin and collagen isoform expression (Ibarz et al. 2013). In contrast, E2-induced suppression of expression of multiple genes involved in wound healing, differentiation and tissue remodeling was found 
Table 2 In vivo effects of $17 \beta$-estradiol on the gene expression of pro-inflammatory mediators, CXC chemokines, and antiinflammatory mediators in the peritoneal leukocytes (PTL).

\begin{tabular}{lll}
\hline Gene & 24 hpi & $96 \mathrm{hpi}$ \\
\hline inos & $1.25 \pm 0.24$ & $1.39 \pm 0.56$ \\
il-1 $\beta$ & $1.24 \pm 0.35$ & $1.49 \pm 0.36$ \\
il-12p35 & $1.23 \pm 0.23$ & $0.74 \pm 0.17$ \\
cxcl8_l2 & $0.77 \pm 0.14$ & $1.51 \pm 0.49$ \\
cxcb2 & $1.65 \pm 0.56$ & $1.37 \pm 0.38$ \\
arginase 1 & $1.43 \pm 0.64$ & $1.78 \pm 0.23$ \\
arginase 2 & $2.56 \pm 0.76$ & $1.22 \pm 0.3$ \\
il-10 & $1.51 \pm 0.32$ & $1.95 \pm 0.35^{*}$ \\
mmp9 & $1.45 \pm 0.29$ & $1.6 \pm 0.45$ \\
\hline
\end{tabular}

Fish were fed for 14 days with control food (non-E2) or food treated with $17 \beta$-estradiol (E2, $20 \mathrm{mg} / \mathrm{kg}$ food). On day 14 of E2 feeding, fish were injected i.p. with A. salmonicida $\left(4 \times 10^{8}\right.$ bacteria in $250 \mu \mathrm{L}$ PBS per fish). At 24 and $96 \mathrm{~h}$ post-infection (hpi), the peritoneal leukocytes were collected, and gene expression was measured. Changes in gene expression are shown as $x$ fold increase compared to control group (non-E2) and standardized for the housekeeping gene $40 \mathrm{~S}$ ribosomal protein s11. Averages and S.E. $(n=7)$. Stars $(*)$ indicate statistically significant differences in the gene expression in PTL derived from fish fed with control (non-E2) and E2-treated food at 24 or 96 hpi (* $p \leq$ $0.05)$

Table 3 In vivo effects of $17 \beta$-estradiol on the gene expression of pro- and anti-inflammatory mediators in the liver.

\begin{tabular}{lll}
\hline Gene & 24 hpi & 96 hpi \\
\hline inos & $1.36 \pm 0.38$ & $0.37 \pm 0.16^{*} \#$ \\
il-1 $\beta$ & $1.51 \pm 0.61$ & $1.34 \pm 0.56$ \\
arginase 1 & $0.66 \pm 0.34$ & $2.2 \pm 1.66$ \\
arginase 2 & $1.12 \pm 0.41$ & $2.24 \pm 0.59$ \\
il-10 & $1.16 \pm 0.45$ & $2.39 \pm 1.9$ \\
c3 & $0.77 \pm 0.1$ & $0.835 \pm 0.4$ \\
crp1 & $0.913 \pm 0.38$ & $0.8 \pm 0.19$ \\
crp2 & $0.48 \pm 0.07 *$ & $0.18 \pm 0.08^{* *}$ \\
\hline
\end{tabular}

Fish were fed for 14 days with control food (non-E2) or food treated with $17 \beta$-estradiol (E2, $20 \mathrm{mg} / \mathrm{kg}$ food). On day $14 \mathrm{of}$ E2 feeding, fish were injected i.p. with A. salmonicida $\left(4 \times 10^{8}\right.$ bacteria in $250 \mu \mathrm{L}$ PBS per fish). At 24 and $96 \mathrm{~h}$ post-infection (hpi), the livers were collected, and gene expression was measured. Changes in gene expression are shown as $x$-fold increase compared to control group (non-E2) and standardized for the housekeeping gene $40 \mathrm{~S}$ ribosomal protein s11. Averages and S.E. $(n=7)$. Stars $(*)$ indicate statistically significant differences in the gene expression in the livers derived from fish fed with control (non-E2) and E2-treated food at 24 or 96 hpi $(* p \leq 0.05$, $* * p \leq 0.001$ ). Number signs (\#) indicate statistically significant differences between fish fed with E2-treated food in two time points (24 hpi vs 96 hpi) $(\# p \leq 0.05)$ in lice-infected skin of Atlantic salmon. In this study E2 also significantly decreased the expression of the IL-4/ 13 genes, cytokines involved in M2 macrophage polarization (Krasnov et al. 2015).

The different in vitro and in vivo effects of E2 that we observed may suggest that during infection, E2 does not affect macrophages in the focus of inflammation only, but rather exerts indirect actions involving other cellular targets or macrophages in other organs/tissues. Most probably, E2-induced reduction of the number of peritoneal leukocytes is correlated to their impaired emigration from the head kidney. Therefore, as mentioned before, the changes in gene expression of pro- and antiinflammatory mediators in the head kidney and in the peritoneum should be also scrutinized in the light of the changes in leukocyte composition.

Conflicting in vitro and in vivo results have been also reported from studies investigating the effects of estrogens on macrophage effector functions in mammals. For example, in striking contrast with in vitro observations, long-term in vivo exposure to estrogens was demonstrated to enhance the LPSinduced transcription of pro-inflammatory cytokines (IL-12 and TNF- $\alpha$ ), by microglial cells through ER $\alpha$-dependent mechanisms (Soucy et al. 2005). Furthermore, despite the confirmation of the antiinflammatory effect of short-term in vitro exposure to E2 on murine resident peritoneal macrophages, Calippe et al. (2008) found contradictory effects in vivo. Chronic in vivo administration of E2 to ovariectomized female mice markedly increased the expression of numerous inflammatory cytokines and of inos in peritoneal macrophages in response to LPS activation ex vivo. The same group (Calippe et al. 2010) found that chronic E2 administration to ovariectomized mice significantly increased the expression of pro-inflammatory cytokines in thioglycolate-elicited macrophages, while disruption of the ER $\alpha$ gene in macrophages totally abolished the effect of E2 on the expression of inflammatory mediators by both resident and inflammatory peritoneal macrophages.

\section{Conclusions}

Our results reveal that E2 can significantly change the anti-bacterial immune response in common carp. We found that estradiol reduces the expression of LPS- 

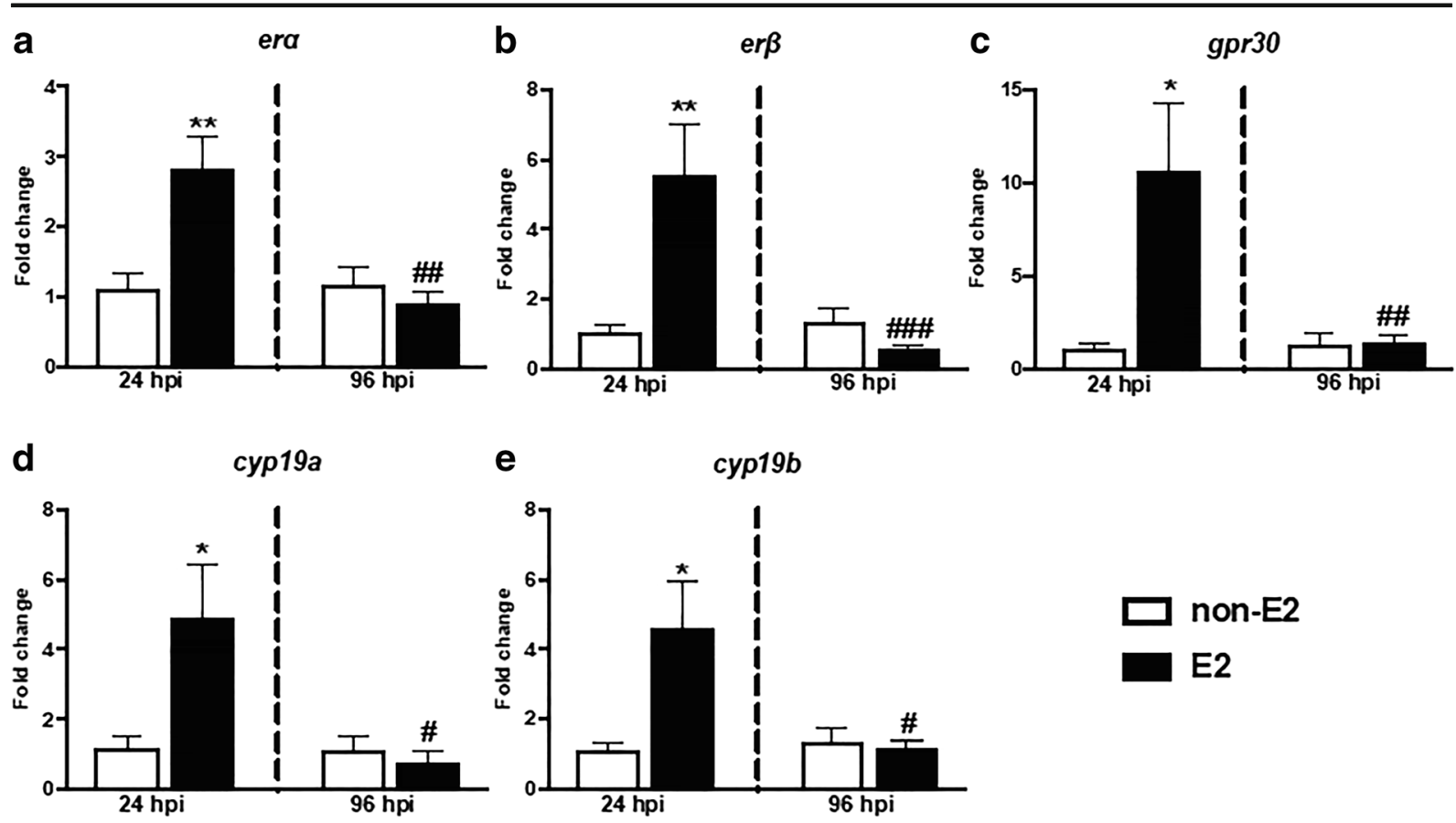

Fig. 9 In vivo effects of $17 \beta$-estradiol on the gene expression of estrogen receptors $(\mathbf{a}-\mathbf{c})$ and aromatase CYP19 $(\mathbf{d}-\mathbf{e})$ in the head kidney. Fish were fed for 14 days with control food (non-E2) or food treated with $17 \beta$-estradiol (E2, $20 \mathrm{mg} / \mathrm{kg}$ food). On day 14 of E2 feeding, fish were injected i.p. with A. salmonicida $\left(4 \times 10^{8}\right.$ bacteria in $250 \mu \mathrm{L}$ PBS per fish). At 24 and $96 \mathrm{~h}$ post-infection (hpi), the head kidneys were collected, and gene expression was measured. Changes in gene expression are shown as $x$-fold

increase compared to control group (non-E2) and standardized for the housekeeping gene 40S ribosomal protein s11. Averages and S.E. $(n=7)$. Stars $(*)$ indicate statistically significant differences between control (CTR) and E2-treated animals $(* p \leq 0.05$, $* * p \leq 0.001$ ); number signs (\#) indicate statistically significant differences between time points of infection (24 vs $96 \mathrm{hpi}$ ) (\#p $\leq$ $0.05, \# \# p \leq 0.001, \# \# p \leq 0.0001$ )

induced pro- and anti-inflammatory mediators in vitro, while in vivo, it decreased the inflammatory reaction. Therefore, we can conclude that estrogens modulate the

inflammatory status of macrophages and other leukocytes and thus alters the ability to mount an effective immune response. This substantiates a significant role

Table 4 In vivo effects of $17 \beta$-estradiol on the gene expression of estrogen receptors and aromatase CYP19 in the peritoneal leukocytes (PTL) and in the liver (LV).

\begin{tabular}{|c|c|c|c|c|}
\hline \multirow[t]{2}{*}{ Gene } & \multicolumn{2}{|l|}{ PTL } & \multicolumn{2}{|l|}{ LV } \\
\hline & 24 hpi & 96 hpi & 24 hpi & 96 hpi \\
\hline er $\alpha$ & $0.59 \pm 0.08$ & $1.47 \pm 0.19 \# \#$ & $12.4 \pm 1.8 * * *$ & $10.1 \pm 0.66^{* * * *}$ \\
\hline$e r \beta$ & $0.74 \pm 0.24$ & $1 \pm 0.17$ & $0.88 \pm 0.24$ & $1.6 \pm 0.32$ \\
\hline gpr30 & $1.2 \pm 0.15$ & $1.33 \pm 0.28$ & $0.2 \pm 0.1^{*}$ & $0.9 \pm 0.25$ \\
\hline cyp19a & $2.27 \pm 0.62$ & $0.3 \pm 0.1 \# \#$ & $0.2 \pm 0.09 *$ & $0.4 \pm 0.9$ \\
\hline cyp19b & $0.59 \pm 0.07$ & $3.84 \pm 1 * * \# \#$ & $0.52 \pm 0.26$ & $1.23 \pm 0.21$ \\
\hline
\end{tabular}

Fish were fed for 14 days with control food (non-E2) or food treated with $17 \beta$-estradiol (E2, $20 \mathrm{mg} / \mathrm{kg}$ food). On day $14 \mathrm{of}$ E2 feeding, fish were injected i.p. with A. salmonicida $\left(4 \times 10^{8}\right.$ bacteria in $250 \mu \mathrm{L}$ PBS per fish). At 24 and $96 \mathrm{~h}$ post-infection (hpi), the peritoneal leukocytes and livers were collected, and gene expression was measured. Changes in gene expression are shown as $x$-fold increase compared to control group (non-E2) and standardized for the housekeeping gene 40 S ribosomal protein s11. Averages and S.E. ( $n=7)$. Stars $(*)$ indicate statistically significant differences in the gene expression in PTLs or livers derived from fish fed with control (non-E2) and E2treated food at 24 or $96 \mathrm{hpi}(* p \leq 0.05$, ***p $\leq 0.0001)$. Number signs (\#) indicate statistically significant differences between fish fed with E2-treated food in two time points (24 hpi vs 96 hpi) (\#p $\leq 0.05, \# \# p \leq 0.001)$ 
for this interplay in the outcome of inflammatory pathologies.

Acknowledgments We like to thank Dr. Krzysztof Rakus, Miriam Mojzesz, and Joanna Szczygiel for their technical support with the bacteria culture and also Dr. Elena Wernicke-von Siebenthal for valuable advices for food preparation.

Authors' contributions M.M. performed the experiments; collected, analyzed, and discussed the data; and wrote the manuscript. L.P. performed some experiments. A.P-S provided A. salmonicida. B.M.L.V-vK discussed the data and co-wrote the manuscript. M.C. co-designed experiments, supervised the study, and co-wrote the manuscript.

Funding information This work was supported by the Polish National Science Center (grant no. 2015/19/B/NZ6/00895).

\section{Compliance with ethical standards}

Conflict of interest The authors declare that they have no competing interests.

Open Access This article is licensed under a Creative Commons Attribution 4.0 International License, which permits use, sharing, adaptation, distribution and reproduction in any medium or format, as long as you give appropriate credit to the original author(s) and the source, provide a link to the Creative Commons licence, and indicate if changes were made. The images or other third party material in this article are included in the article's Creative Commons licence, unless indicated otherwise in a credit line to the material. If material is not included in the article's Creative Commons licence and your intended use is not permitted by statutory regulation or exceeds the permitted use, you will need to obtain permission directly from the copyright holder. To view a copy of this licence, visit http://creativecommons.org/licenses/by/4.0/.

\section{References}

Akbary P, Mirvaghefi A, Akhlaghi M et al (2013) Effects of the aromatase inhibitore letrozole on serum immunoglobulin and lysozyme levels in immunized rainbow trout (Oncorhynchus mykiss Walbaum) females. Int J Aquat Biol 1:273-280. https://doi.org/10.22034/ijab.v1i6.143

Arts JAJ, Tijhaar EJ, Chadzinska M, Savelkoul HFJ, Verburg-van Kemenade BML (2010) Functional analysis of carp interferon- $\gamma$ : evolutionary conservation of classical phagocyte activation. Fish Shellfish Immunol 29:793-802. https://doi. org/10.1016/j.fsi.2010.07.010

Ashcroft GS, Mills SJ, Lei K, Gibbons L, Jeong MJ, Taniguchi M, Burow M, Horan MA, Wahl SM, Nakayama T (2003) Estrogen modulates cutaneous wound healing by downregulating macrophage migration inhibitory factor. J Clin Invest 111:1309-1318. https://doi.org/10.1172 /JCI16288

Bai S, Thummel R, Godwin AR et al (2005) Matrix metalloproteinase expression and function during fin regeneration in zebrafish: analysis of MT1-MMP, MMP2 and TIMP2. Matrix Biol 24:247-260. https://doi.org/10.1016/j. matbio.2005.03.007

Bayne CJ, Gerwick L (2001) The acute phase response and innate immunity of fish. Dev Comp Immunol 25:725-743. https://doi.org/10.1016/S0145-305X(01)00033-7

Bengtsson ÅK, Ryan EJ, Giordano D et al (2004) 17 $\beta$-estradiol (E2) modulates cytokine and chemokine expression in human monocyte-derived dendritic cells. Blood 104:14041410. https://doi.org/10.1182/blood-2003-10-3380

Burgos-Aceves MA, Cohen A, Smith Y, Faggio C (2016) Estrogen regulation of gene expression in the teleost fish immune system. Fish Shellfish Immunol 58:42-49. https://doi.org/10.1016/j.fsi.2016.09.006

Cabas I, Liarte S, García-Alcázar A, Meseguer J, Mulero V, García-Ayala A (2012) 17 $\alpha$-Ethynylestradiol alters the immune response of the teleost gilthead seabream (Sparus aurata L.) both in vivo and in vitro. Dev Comp Immunol 36:547-556. https://doi.org/10.1016/j.dci.2011.09.011

Calippe B, Douin-Echinard V, Laffargue M, Laurell H, RanaPoussine V, Pipy B, Guéry JC, Bayard F, Arnal JF, Gourdy $\mathrm{P}$ (2008) Chronic estradiol administration in vivo promotes the proinflammatory response of macrophages to TLR4 activation: involvement of the phosphatidylinositol 3-kinase pathway. J Immunol 180:7980-7988. https://doi. org/10.4049/jimmunol.180.12.7980

Calippe B, Douin-Echinard V, Delpy L, Laffargue M, Lélu K, Krust A, Pipy B, Bayard F, Arnal JF, Guéry JC, Gourdy P (2010) 17ß-Estradiol promotes TLR4-triggered proinflammatory mediator production through direct estrogen receptor $\alpha$ signaling in macrophages in vivo. J Immunol 185:11691176. https://doi.org/10.4049/jimmunol.0902383

Campbell L, Emmerson E, Davies F, Gilliver SC, Krust A, Chambon P, Ashcroft GS, Hardman MJ (2010) Estrogen promotes cutaneous wound healing via estrogen receptor $\beta$ independent of its antiinflammatory activities. J Exp Med 207:1825-1833. https://doi.org/10.1084/jem.20100500

Campbell L, Saville CR, Murray PJ, Cruickshank SM, Hardman MJ (2013) Local arginase 1 activity is required for cutaneous wound healing. J Invest Dermatol 133:2461-2470. https://doi.org/10.1038/jid.2013.164

Campbell L, Emmerson E, Williams H, Saville CR, Krust A, Chambon P, Mace KA, Hardman MJ (2014) Estrogen receptor-alpha promotes alternative macrophage activation during cutaneous repair. J Invest Dermatol 134:2447-2457. https://doi.org/10.1038/jid.2014.175

Chadzinska M, Baginski P, Kolaczkowska E, Savelkoul HFJ, Lidy Verburg-van Kemenade BM (2008a) Expression profiles of matrix metalloproteinase 9 in teleost fish provide evidence for its active role in initiation and resolution of inflammation. Immunology 125:601-610. https://doi. org/10.1111/j.1365-2567.2008.02874.x

Chadzinska M, Leon-Kloosterziel KM, Plytycz B, Verburg-van Kemenade BML (2008b) In vivo kinetics of cytokine expression during peritonitis in carp: evidence for innate and 
alternative macrophage polarization. Dev Comp Immunol 32:509-518. https://doi.org/10.1016/j.dci.2007.08.008

Chadzinska M, Savelkoul HFJ, Verburg-van Kemenade BML (2009) Morphine affects the inflammatory response in carp by impairment of leukocyte migration. Dev Comp Immunol 33:88-96. https://doi.org/10.1016/j.dci.2008.07.004

Chaves-Pozo E, García-Ayala A, Cabas I (2018) Effects of sex steroids on fish leukocytes. Biology (Basel) 7:9. https://doi. org/10.3390/biology7010009

Corraliza IM, Campo ML, Soler G, Modolell M (1994) Determination of arginase activity in macrophages: a micromethod. J Immunol Methods 174:231-235. https://doi. org/10.1016/0022-1759(94)90027-2

Costa RA, Power DM (2018) Skin and scale regeneration after mechanical damage in a teleost. Mol Immunol 95:73-82. https://doi.org/10.1016/j.molimm.2018.01.016

Derlindati E, Cas AD, Montanini B et al (2015) Transcriptomic analysis of human polarized macrophages: more than one role of alternative activation? PLoS One 10:1-17. https://doi. org/10.1371/journal.pone.0119751

Emmerson E, Campbell L, Ashcroft GS, Hardman MJ (2009) Unique and synergistic roles for $17 \beta$-estradiol and macrophage migration inhibitory factor during cutaneous wound closure are cell type specific. Endocrinology 150:2749-2757. https://doi.org/10.1210/en.2008-1569

Falco A, Frost P, Miest J, Pionnier N, Irnazarow I, Hoole D (2012) Reduced inflammatory response to Aeromonas salmonicida infection in common carp (Cyprinus carpio L.) fed with $\beta$ glucan supplements. Fish Shellfish Immunol 32:1051-1057. https://doi.org/10.1016/j.fsi.2012.02.028

Ghisletti S, Meda C, Maggi A, Vegeto E (2005) 17 $\beta$-Estradiol inhibits inflammatory gene expression by controlling NF-kB intracellular localization. Mol Cell Biol 25:2957-2968. https://doi.org/10.1128/mcb.25.8.2957-2968.2005

Godwin JW, Debuque R, Salimova E, Rosenthal NA (2017) Heart regeneration in the salamander relies on macrophagemediated control of fibroblast activation and the extracellular landscape. NPJ Regen Med 2:1-11. https://doi.org/10.1038 /s41536-017-0027-y

Gruca P, Chadzinska M, Lackowska B, Plytycz B (1996) Analysis of peritoneal and head kidney phagocytes during Thioglycollate-elicited peritoneal inflammation in the goldfish, Carassius auratus. Folia Biol (Praha) 44:137-142

Guerrero RD (1975) Use of androgens for the production of allmale Tilapia aurea (Steindachner). Trans Am Fish Soc 104: 342-348. https://doi.org/10.1577/1548-8659(1975)104<342 $: \mathrm{UOAFTP}>2.0 . \mathrm{CO} ; 2$

Hawkins MB, Thomas P (2004) The unusual binding properties of the third distinct teleost estrogen receptor subtype ER $\beta a$ are accompanied by highly conserved amino acid changes in the ligand binding domain. Endocrinology 145:2968-2977. https://doi.org/10.1210/en.2003-0806

Hodgkinson JW, Fibke C, Belosevic M (2017) Recombinant IL-4/ $13 \mathrm{~A}$ and IL-4/13B induce arginase activity and downregulate nitric oxide response of primary goldfish (Carassius auratus L.) macrophages. Dev Comp Immunol 67:377-384. https://doi.org/10.1016/j.dci.2016.08.014

Holm A, Andersson KE, Nordström I, Hellstrand P, Nilsson BO (2010) Down-regulation of endothelial cell estrogen receptor expression by the inflammation promoter LPS. Mol Cell
Endocrinol 319:8-13. https://doi.org/10.1016/j. mce.2010.01.002

Hui SP, Sheng DZ, Sugimoto K, Gonzalez-Rajal A, Nakagawa S, Hesselson D, Kikuchi K (2017) Zebrafish regulatory T cells mediate organ-specific regenerative programs. Dev Cell 43: 659-672. https://doi.org/10.1016/j.devcel.2017.11.010

Ibarz A, Pinto PIS, Power DM (2013) Proteomic approach to skin regeneration in a marine teleost: modulation by oestradiol17ß. Mar Biotechnol 15:629-646. https://doi.org/10.1007 /s10126-013-9513-4

Iwanowicz LR, Stafford JL, Patiño R, Bengten E, Miller NW, Blazer VS (2014) Channel catfish (Ictalurus punctatus) leukocytes express estrogen receptor isoforms $\mathrm{ER} \alpha$ and $\mathrm{ER} \beta 2$ and are functionally modulated by estrogens. Fish Shellfish Immunol 40:109-119. https://doi.org/10.1016/j. fsi.2014.06.021

Jaźwińska A, Badakov R, Keating MT (2007) Activin- $\beta$ A signaling is required for zebrafish fin regeneration. Curr Biol 17: 1390-1395. https://doi.org/10.1016/j.cub.2007.07.019

Joerink M, Savelkoul HFJ, Wiegertjes GF (2006) Evolutionary conservation of alternative activation of macrophages: structural and functional characterization of arginase 1 and 2 in carp (Cyprinus carpio L.). Mol Immunol 43:1116-1128. https://doi.org/10.1016/j.molimm.2005.07.022

Katsu Y, Lange A, Miyagawa S, Urushitani H, Tatarazako N, Kawashima Y, Tyler CR, Iguchi T (2013) Cloning, expression and functional characterization of carp, Cyprinus carpio , estrogen receptors and their differential activations by estrogens. J Appl Toxicol 33:41-49. https://doi.org/10.1002 /jat.1707

Krasnov A, Wesmajervi Breiland MS, Hatlen B, Afanasyev S, Skugor S (2015) Sexual maturation and administration of $17 \beta$-estradiol and testosterone induce complex gene expression changes in skin and increase resistance of Atlantic salmon to ectoparasite salmon louse. Gen Comp Endocrinol 212:34 43. https://doi.org/10.1016/j.ygcen.2015.01.002

Lau LF (2011) CCN1/CYR61: the very model of a modern matricellular protein. Cell Mol Life Sci 68:3149-3163. https://doi.org/10.1007/s00018-011-0778-3

Law WY, Chen WH, Song YL, Dufour S, Chang CF (2001) Differential in vitro suppressive effects of steroids on leukocyte phagocytosis in two teleosts, tilapia and common carp. Gen Comp Endocrinol 121:163-172. https://doi.org/10.1006 /gcen.2000.7593

LeBert DC, Squirrell JM, Rindy J et al (2015) Matrix metalloproteinase 9 modulates collagen matrices and wound repair. Dev 142:2136-2146. https://doi.org/10.1242/dev.121160

Liarte S, Cabas I, Chaves-Pozo E, Arizcun M, Meseguer J, Mulero V, García-Ayala A (2011a) Natural and synthetic estrogens modulate the inflammatory response in the gilthead seabream (Sparus aurata L.) through the activation of endothelial cells. Mol Immunol 48:1917-1925. https://doi.org/10.1016/j. molimm.2011.05.019

Liarte S, Chaves-Pozo E, Abellán E, Meseguer J, Mulero V, García-Ayala A (2011b) 17 $\beta$-Estradiol regulates gilthead seabream professional phagocyte responses through macrophage activation. Dev Comp Immunol 35:19-27. https://doi. org/10.1016/j.dci.2010.07.007

López-Muñoz A, Liarte S, Gómez-González NE, Cabas I, Meseguer J, García-Ayala A, Mulero V (2015) Estrogen receptor $2 \mathrm{~b}$ deficiency impairs the antiviral response of 
zebrafish. Dev Comp Immunol 53:55-62. https://doi. org/10.1016/j.dci.2015.06.008

Maciuszek M, Rydz L, Świtakowska I, Verburg-van Kemenade BML, Chadzińska M (2019) Effects of stress and cortisol on the polarization of carp macrophages. Fish Shellfish Immunol 94:27-37. https://doi.org/10.1016/j. fsi.2019.08.064

Magnadóttir B (2006) Innate immunity of fish (overview). Fish Shellfish Immunol 20:137-151. https://doi.org/10.1016/j. fsi.2004.09.006

Mao K, Chen W, Mu Y, Ao J, Chen X (2018) Identification of two IL-4/13 homologues in large yellow croaker (Larimichthys crocea) revealed their similar roles in inducing alternative activation of monocytes/macrophages. Fish Shellfish Immunol 80:180-190. https://doi.org/10.1016/j. fsi.2018.06.002

Martinez FO, Gordon S (2014) The M1 and M2 paradigm of macrophage activation: time for reassessment. F1000Prime Rep 6:13. https://doi.org/10.12703/P6-13

Matthews J, Gustafsson JA (2003) Estrogen signaling: a subtle balance between ER alpha and ER beta. Mol Interv 3:281292. https://doi.org/10.1124/mi.3.5.281

Montero J, Gómez-Abellán V, Arizcun M, Mulero V, Sepulcre MP (2016) Prostaglandin E2 promotes M2 polarization of macrophages via a cAMP/CREB signaling pathway and deactivates granulocytes in teleost fish. Fish Shellfish Immunol 55:632-641. https://doi.org/10.1016/j. fsi.2016.06.044

Ogawa K, Funaba M, Chen Y, Tsujimoto M (2006) Activin a functions as a Th2 cytokine in the promotion of the alternative activation of macrophages. J Immunol 177:6787-6794. https://doi.org/10.4049/jimmunol.177.10.6787

Paiola M, Moreira C, Duflot A, Knigge T, Monsinjon T (2019) Oestrogen differentially modulates lymphoid and myeloid cells of the European sea bass in vitro by specifically regulating their redox biology. Fish Shellfish Immunol 86:713723. https://doi.org/10.1016/j.fsi.2018.11.078

Pfaffl MW (2001) A new mathematical model for relative quantification in real-time RT-PCR. Nucleic Acids Res 29:45e. https://doi.org/10.1093/nar/29.9.e45

Pioli PA, Jensen AL, Weaver LK, Amiel E, Shen Z, Shen L, Wira CR, Guyre PM (2007) Estradiol attenuates lipopolysaccharide-induced CXC chemokine ligand 8 production by human peripheral blood monocytes. J Immunol 179:6284-6290. https://doi.org/10.4049 /jimmunol.179.9.6284

Rastgar S, Movahedinia A, Salamat N, Salati AP, Zabihi E (2019) Interruption of immune responses in primary macrophages exposed to nonylphenol provides insights into the role of ER and NF-KB in immunotoxicity of Persian sturgeon. Fish Shellfish Immunol 86:125-134. https://doi.org/10.1016/j. fsi.2018.11.038

Rath M, Müller I, Kropf P et al (2014) Metabolism via arginase or nitric oxide synthase: two competing arginine pathways in macrophages. Front Immunol 5:1-10. https://doi. org/10.3389/fimmu.2014.00532

Robertson LS, Iwanowicz LR, Marranca JM (2009) Identification of centrarchid hepcidins and evidence that $17 \beta$-estradiol disrupts constitutive expression of hepcidin-1 and inducible expression of hepcidin-2 in largemouth bass (Micropterus salmoides). Fish Shellfish Immunol 26:898-907. https://doi. org/10.1016/j.fsi.2009.03.023

Routley CE, Ashcroft GS (2009) Effect of estrogen and progesterone on macrophage activation during wound healing. Wound Repair Regen 17:42-50. https://doi.org/10.1111 j.1524-475X.2008.00440.x

Seemann F, Knigge T, Rocher B, Minier C, Monsinjon T (2013) $17 \beta$-estradiol induces changes in cytokine levels in head kidney and blood of juvenile sea bass (Dicentrarchus labrax, L., 1758). Mar Environ Res 87-88:44-51. https://doi. org/10.1016/j.marenvres.2013.03.003

Shelley LK, Ross PS, Kennedy CJ (2012) The effects of an in vitro exposure to $17 \beta$-estradiol and nonylphenol on rainbow trout (Oncorhynchus mykiss) peripheral blood leukocytes. Comp Biochem Physiol - C Toxicol Pharmacol 155:440-446. https://doi.org/10.1016/j.cbpc.2011.11.006

Shelley LK, Osachoff HL, van Aggelen GC, Ross PS, Kennedy CJ (2013) Alteration of immune function endpoints and differential expression of estrogen receptor isoforms in leukocytes from $17 \beta$-estradiol exposed rainbow trout (Oncorhynchus mykiss). Gen Comp Endocrinol 180:24-32. https://doi.org/10.1016/j.ygcen.2012.09.014

Sierra A, Gottfried-Blackmore A, Milner TA, McEwen BS, Bulloch K (2008) Steroid hormone receptor expression and function in microglia. Glia 56:659-674. https://doi. org/10.1002/glia.20644

Soucy G, Boivin G, Labrie F, Rivest S (2005) Estradiol is required for a proper immune response to bacterial and viral pathogens in the female brain. J Immunol 174:6391-6398. https://doi. org/10.4049/jimmunol.174.10.6391

Szwejser E, Maciuszek M, Casanova-Nakayama A, Segner H, Verburg-van Kemenade BML, Chadzinska M (2017a) A role for multiple estrogen receptors in immune regulation of common carp. Dev Comp Immunol 66:61-72. https://doi. org/10.1016/j.dci.2016.04.003

Szwejser E, Pijanowski L, Maciuszek M, Ptak A, Wartalski K, Duda M, Segner H, Verburg-van Kemenade BML, Chadzinska M (2017b) Stress differentially affects the systemic and leukocyte estrogen network in common carp. Fish Shellfish Immunol 68:190-201. https://doi.org/10.1016/j. fsi.2017.07.011

Szwejser E, Verburg-van Kemenade BML, Maciuszek M, Chadzinska M (2017c) Estrogen-dependent seasonal adaptations in the immune response of fish. Horm Behav 88:15-24. https://doi.org/10.1016/j.yhbeh.2016.10.007

Thilagam H, Gopalakrishnan S, Bo J, Wang KJ (2009) Effect of $17 \beta$-estradiol on the immunocompetence of Japanese sea bass (Lateolabrax japonicus). Environ Toxicol Chem 28: 1722-1731. https://doi.org/10.1897/08-642.1

van der Aa LM, Chadzinska M, Golbach LA, Ribeiro CMS, Lidy Verburg-van Kemenade BM (2012) Pro-inflammatory functions of carp CXCL8-like and $\mathrm{CXCb}$ chemokines. Dev Comp Immunol 36:741-750. https://doi.org/10.1016/j. dci.2011.11.011

Vegeto E, Ghisletti S, Meda C, Etteri S, Belcredito S, Maggi A (2004) Regulation of the lipopolysaccharide signal transduction pathway by $17 \beta$-estradiol in macrophage cells. J Steroid Biochem Mol Biol 91:59-66. https://doi.org/10.1016/j. jsbmb.2004.02.004

Verburg-van Kemenade BML, Groeneveld A, van Rens BTTM, Rombout JHWM (1994) Characterization of macrophages 
and neutrophilic granulocytes from the pronephros of carp (Cyprinus carpio). J Exp Biol 187:143158 http://www.ncbi. nlm.nih.gov/pubmed/9317515

Verburg-van Kemenade BML, Cohen N, Chadzinska M (2017) Neuroendocrine-immune interaction: evolutionarily conserved mechanisms that maintain allostasis in an everchanging environment. Dev Comp Immunol 66:2-23. https://doi.org/10.1016/j.dci.2016.05.015

Villa A, Rizzi N, Vegeto E, Ciana P, Maggi A (2015) Estrogen accelerates the resolution of inflammation in macrophagic cells. Sci Rep 5:15224. https://doi.org/10.1038/srep15224

Wang R, Belosevic M (1994) Estradiol increases susceptibility of goldfish to Trypanosoma danilewskyi. Dev Comp Immunol 18:377-387. https://doi.org/10.1016/0145-305x(94)90003-5

Wang R, Belosevic M (1995) The in vitro effects of estradiol and cortisol on the function of a long-term goldfish macrophage cell line. Dev Comp Immunol 19:327-336. https://doi. org/10.1016/0145-305x(95)00018-o

Watanuki H, Yamaguchi T, Sakai M (2002) Suppression in function of phagocytic cells in common carp Cyprinus carpio L. injected with estradiol, progesterone or 11-ketotestosterone. Comp Biochem Physiol C Toxicol Pharmacol 132:407-413. https://doi.org/10.1016/S1532-0456(02)00100-X
Wenger M, Sattler U, Goldschmidt-Clermont E, Segner H (2011) 17Beta-estradiol affects the response of complement components and survival of rainbow trout (Oncorhynchus mykiss) challenged by bacterial infection. Fish Shellfish Immunol 31: 90-97. https://doi.org/10.1016/j.fsi.2011.04.007

Yamaguchi T, Watanuki H, Sakai M (2001) Effects of estradiol, progesterone and testosterone on the function of carp, Cyprinus carpio, phagocytes in vitro. Comp Biochem Physiol C Toxicol Pharmacol 129:49-55. https://doi. org/10.1016/S1532-0456(01)00176-4

Yang W, Lu Y, Xu Y, Xu L, Zheng W, Wu Y, Li L, Shen P (2012) Estrogen represses hepatocellular carcinoma (HCC) growth via inhibiting alternative activation of tumor-associated macrophages (TAMs). J Biol Chem 287:40140-40149. https://doi.org/10.1074/jbc.M1 12.348763

Y in D, Hu S, Gu Y et al (2007) Immunotoxicity of bisphenol A to Carassius auratus lymphocytes and macrophages following in vitro exposure. J Environ Sci 19:232-237. https://doi. org/10.1016/S1001-0742(07)60038-2

Publisher's note Springer Nature remains neutral with regard to jurisdictional claims in published maps and institutional affiliations. 